\title{
Article
}

\section{Quantifying the Relative Contribution of Climate Change and Anthropogenic Activities on Runoff Variations in the Central Part of Tajikistan in Central Asia}

\author{
Nekruz Gulahmadov 1,2,3 $\mathbb{D}_{\text {, Yaning Chen }}^{1, *}$, Aminjon Gulakhmadov 1,3,4 $\mathbb{D}$, Moldir Rakhimova 1,2 \\ and Manuchekhr Gulakhmadov $1,2,5$ iD \\ 1 State Key Laboratory of Desert and Oasis Ecology, Xinjiang Institute of Ecology and Geography, \\ Chinese Academy of Sciences, Urumqi 830011, China; nekruz.abdujabborovich@mails.ucas.ac.cn (N.G.); \\ aminjon@ms.xjb.ac.cn (A.G.); moldirrakhimova@gmail.com (M.R.); gmanuchekhr@mail.ru (M.G.) \\ 2 University of Chinese Academy of Sciences, Beijing 100049, China \\ 3 Institute of Water Problems, Hydropower and Ecology of the Academy of Sciences of the Republic of \\ Tajikistan, Dushanbe 734042, Tajikistan \\ 4 Ministry of Energy and Water Resources of the Republic of Tajikistan, Dushanbe 734064, Tajikistan \\ 5 Committee for Environmental Protection under the Government of the Republic of Tajikistan, \\ Dushanbe 734034, Tajikistan \\ * Correspondence: chenyn@ms.xjb.ac.cn; Tel.: +86-991-782-3169
}

check for updates

Citation: Gulahmadov, N.; Chen, Y.; Gulakhmadov, A.; Rakhimova, M.; Gulakhmadov, M. Quantifying the Relative Contribution of Climate Change and Anthropogenic Activities on Runoff Variations in the Central Part of Tajikistan in Central Asia. Land 2021, 10, 525. https:// doi.org/10.3390/land10050525

Academic Editors:

Ebrahim Ahmadisharaf,

Saurav Kumar and Vamsi

Krishna Sridharan

Received: 12 April 2021

Accepted: 9 May 2021

Published: 14 May 2021

Publisher's Note: MDPI stays neutral with regard to jurisdictional claims in published maps and institutional affiliations.

Copyright: (c) 2021 by the authors. Licensee MDPI, Basel, Switzerland. This article is an open access article distributed under the terms and conditions of the Creative Commons Attribution (CC BY) license (https:/ / creativecommons.org/licenses/by/ $4.0 /)$.

\begin{abstract}
Quantifying the relative contribution of climate change and anthropogenic activities to runoff alterations are essential for the sustainable management of water resources in Central Asian countries. In the Kofarnihon River Basin (KRB) in Central Asia, both changing climate conditions and anthropogenic activities are known to have caused changes to the hydrological cycle. Therefore, quantifying the net influence of anthropogenic contribution to the runoff changes is a challenge. This study applied the original and modified Mann-Kendall trend test, including the Sen's slope test, Pettitt's test, double cumulative curve, and elasticity methods. These methods were applied to determine the historical trends, magnitude changes and change points of the temperature, precipitation, potential evapotranspiration, and runoff from 1950 to 2016. In addition, the contributions of climate change and anthropogenic activities to runoff changes in the KRB were evaluated. The trend analysis showed a significant increasing trend in annual temperature and potential evapotranspiration, while the annual precipitation trend showed an insignificant decreasing trend during the 1950-2016 time period. The change point in runoff occurred in 1986 in the upstream region and 1991 in the downstream region. Further, the time series (1950-2016) is separated into the prior impacted period (1950-1986 and 1950-1991) and post impacted period (1987-2016 and 1992-2016) for the upstream and downstream regions, respectively. During the post impacted period, climate change and anthropogenic activities contributed to $87.96 \%$ and $12.04 \%$ in the upstream region and $7.53 \%$ and $92.47 \%$ in the downstream region of the KRB. The results showed that in runoff changes, the anthropogenic activities played a dominant role in the downstream $(97.78 \%)$ and the climate change impacts played a dominant factor in the upstream region (87.96\%). In the land-use type changes, the dominant role was played by construction land, which showed that the area from $248.63 \mathrm{~km}^{2}$ in 1990 increased to $685.45 \mathrm{~km}^{2}$ (175.69\%) in 2015. These findings suggest that it is essential to adopt effective steps for the sustainable development of the ecological, hydrological, and social order in the $\mathrm{KRB}$ in Central Asia.
\end{abstract}

Keywords: runoff variation; climate change; human activities; MK test; climate elasticity; Kofarnihon River Basin

\section{Introduction}

In recent years, due to the variations in water resources and the frequent reoccurrence of natural disasters, studies estimating the hydrological response to climate variability and 
anthropogenic activities have attracted more attention. In many basins worldwide, the variations in the climate and human disturbances cause serious changes in the ecological and hydrological patterns [1-3]. Such variations also lead to changes in hydrological processes in the mountainous areas, causing more serious problems for water availability in the downstream areas in the arid and semi-arid areas [4-6]. The hydrological cycle is the driving factor for the physical and ecological processes on the Earth's surface. Runoff is closely associated with each aspect of anthropogenic activity, by affecting land use, agricultural irrigation, vegetation growth, construction of hydraulic structures, and the quality and volume of available water for provincial uses $[7,8]$. Additionally, variations in runoff can lead to various ecological and hydrological difficulties, and this is particularly critical for areas with limited water resources $[9,10]$. Thus, it is especially important to evaluate the responses of hydrological regimes to climate variability and anthropogenic activities to improve our knowledge of hydrological regimes and develop scientifically based strategies for sustainable supervision in the case of water resources management.

The formation of runoffs has been influenced by several factors, including air temperature, atmospheric rainfalls, landscape, plant cover, and soil structure [11]. The influence of different factors on runoff has been investigated by earlier works, among which climate variability and anthropogenic activities have abundant implications. Wang et al. studied the influence of climate and land practice variations on runoff in the Haihe River Basin, and in this catchment, the forest has a strong impact on runoff under climate change [12]. Alizadeh et al. and Dong et al. pointed out that various reaches of the basin were influenced contrarily by climatic and human influences $[13,14]$. Oki et al. presented the idea that global warming induces the changes of the regional continuous circulation of water, which will indirectly induce variations in runoff [15]. The extensive utilization of water resources has led to large changes in surface water and direct or indirect alterations in the measurable and qualitative features of runoff, which could be caused by the human disturbances of the natural environment and formation the river basin landscape [16,17].

To identify the effect of climate variability and anthropogenic disturbances, different hydrological models have been applied in Southeastern Asia, whereas only a few studies have captured in Central Asia [3,6,14,18-32]. The linear regression model, the climate elasticity method, Budyko's curve method, hydrological sensitivity, and the Soil and Water Assessment Tool (SWAT) hydrologic model were used to estimate the impacts of human disturbances and climate change on runoff variability in the Dongjiang, Beiluo, Yan, Jumar, and Red River basins in China $[3,21,28,33]$. The precipitation-runoff double cumulative curve methods, the non-parametric Pettitt test, Kendall's test, the modified Mann-Kendall test, and Sen's slope estimator were applied to compute the change point, trends, and magnitude of the annual runoff in the Nenjiang, Shiyang, Ganjiang, and Songhua River Basins in China, Tapi Basin in West Central India, and Soyang Dam upper Basin and the Seom River Basin in South Korea [14,20,29,33-35]. In Central Asia, Xue et al. [6] quantitatively analyzed the factors that caused climatic and anthropogenic disturbances to the variation of the runoff in the Tarim River Basin by applying the double cumulative curve and Budyko methods. The sensitivity analysis from their study showed that the runoff is most susceptible to variability in landscape parameters. Bissenbayeva et al. [31], based on potential evapotranspiration and precipitation, applied the hydrological sensitivity method to assess the influences of climate change and anthropogenic disturbances on runoff during 1960-2015 in the Arys River Basin and Keles River Basin in Central Asia. The result of the hydrological sensitivity method showed that in both basins, the annual runoff decreased due to anthropogenic factors (from 59\% to 99\%) [31]. The climate elasticity, double cumulative curve methods, Pettitt test, and Mann-Kendall trend test was used by Rakhimova et al. in the Buqtyrma River Basin in Central Asia [30]. Rakhimova et al. reported that the impacts caused by climate variability in the changes of runoff were larger in the upper reaches of the catchment $(70 \%)$, compared with those in the middle $(62.11 \%)$ and lower reaches of the Buqtyrma River Basin (15.34\%), while changes in runoff was stronger $(84.66 \%)$ in the lower reaches, which was induced by human disturbances. 
Our previous study in which the SWAT model was applied in the mountainous Vakhsh River Basin (VRB) in Central Asia [32] showed that the hydrologic response to climate variations had significant effects on runoff changes. It was found that global warming accelerated the process of snow/glacier melting, which induced an increasing runoff in the VRB in the past recent decades [32]. In this study, the variability in runoff to climate change and anthropogenic disturbances were separated, which significantly varied from basin to basin [36,37]. Empirical statistical methods based on the historical hydro-climatic data series typically create the ratio of runoff and climatic factors [3,38]. Moreover, the empirical statistical approach could be aggregated with the Budyko analysis and double cumulative curve method [3,39-41]. Hydrological models such as the physical-based semi-distributed SWAT model [42], MIKE SHE [43], variable infiltration capacity [44], generalized additive model [45] and Hydrologic Engineering Center's-Hydrologic Modeling System (HECHMS) [46,47], are consistent in quantifying the effect of climate change on runoff. However, these hydrological models generally require different datasets, which often restrict their application in some river basins with limited records [48]. The climatic elasticity method is a useful and alternative method for quantifying variations in runoff, which was suggested by Fu, Zhang, Arora, Wang, and Budyko [49-52].

Following the foregoing literature review, it was found that the climate elasticity model is applicable to determine the annual runoff sensitivity to climate variability. The climate elasticity method is widely applied to divide the runoff response between climate change and anthropogenic activities [25,49,50,53]. Accordingly, this paper will adopt the climate elasticity method in the Kofarnihon River Basin (KRB) in Central Asia. To the best of our knowledge, the quantitative study of the response of hydrological regimes to climate variability and anthropogenic intervention has not yet been conducted in the KRB in Central Asia. Over the past few decades, urbanization and irrigation have been influencing the utilization of water resources in the midstream and downstream areas of the KRB. This study will comprehensively enhance our understanding of the runoff process and develop scientifically based plans for sustainable management of water resources in the upstream and downstream regions of the KRB [54,55].

The objectives of this study are (1) to statistically determine the presence or absence of variable trends and the critical change point in annual hydro-climatic variables, including potential evapotranspiration, temperature, precipitation, and runoff at both Dahana and Tartki Stations in the KRB from 1950 to 2016; (2) to investigate the sensitivity and contribution rate of the influences of climate variations and anthropogenic interferences to runoff changing processes and (3) to estimate the contribution of their impacts along the upper and lower reaches in the KRB. The findings of this study will be of great benefit to long-term planning, management, and conservation of water resources in the surrounding areas. The study will ensure water and food security by proposing appropriate measures to mitigate the consequences of the devastating effects of climatic change.

\section{Materials and Methods}

\subsection{Study Area}

The Kofarnihon River (KR) is the third largest inflow of the Amu Darya River (ADR) and it flows through Tajikistan and partially forms the border between Tajikistan and Uzbekistan in Central Asia and lies between longitude $68^{\circ}-70^{\circ} \mathrm{E}$ and latitude $37^{\circ}-39^{\circ} \mathrm{N}$. The KR flows into ADR $36 \mathrm{~km}$ below in the confluence of the Panj and Vakhsh rivers. Before reaching the ADR, the total distance of the KR is $387 \mathrm{~km}$ and the overall area of the basin is $11,590 \mathrm{~km}^{2}$, of which $8070 \mathrm{~km}^{2}$ is a mountainous area [56]. Elevation in the Kofarnihon River Basin ranges from 304 to $4830 \mathrm{~m}$ above sea level (Figure 1). 


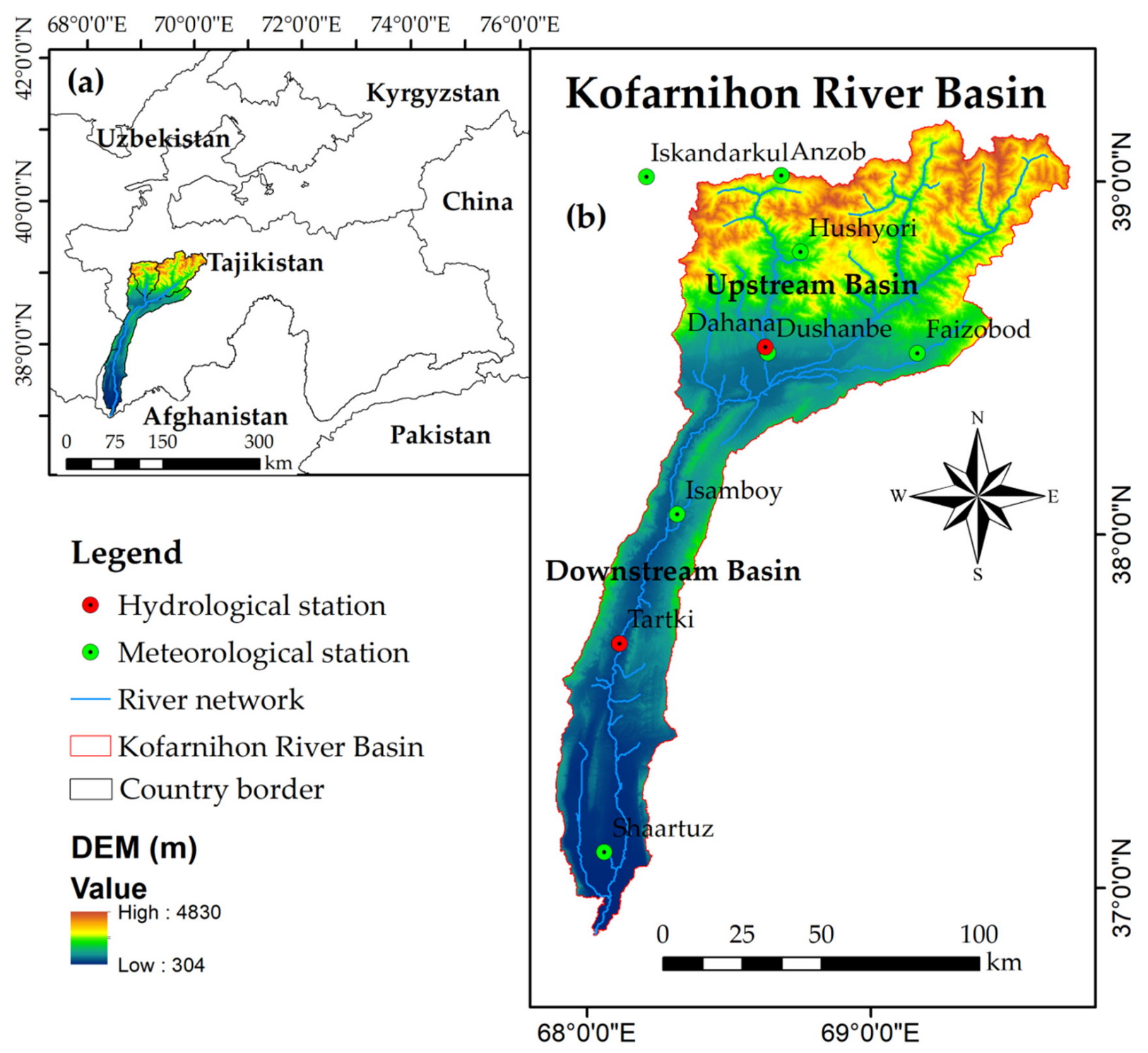

Figure 1. (a) Location of the study area; (b) digital elevation model, hydrological, and meteorological stations.

The KR originates from a glacier located at the junction of the Gissar and Karategin ranges and flows into the ADR. The KR flows from the north-east to the south-west, and then after Dushanbe city, it turns to the south. The KR originates from the Kaniz River in the upper reaches. Almost $50 \mathrm{~km}$ from the source of the Kaniz River, it merges with the high-water Khonaqo River, after which it receives the name Sorvo. Downstream, near the village of Romit, the Sorvo River flows into the large river of Sardai-Miyona. The SardaiMiyona River takes three small tributaries with insignificant glaciation in the upper parts. The Sardai-Miyona River on the right receives the largest tributary named the Kapandor River. The Kapandor River flows mainly to the east, taking large tributaries on their way from the left- the Loylyakul and Arkhu rivers. Below the confluence of the Kapandor River, the Sardai-Miyona River receives on the left side two more small tributaries-the Akbayras and Aukul streams. After the confluence of the Sorvo and Sardai-Miyona rivers, the river receives the name Kofarnihon. Below the village of Romit, the Obiyos River flows into the Kofarnihon River. Not far from the capital city-Dushanbe, in the Kofarnihon River-falls the largest right tributary named Varzob River, formed from the confluence of the Ziddi and Maykhura rivers. Below the mouth of the Maykhura River, on the right, the Siyoma River flows into the Varzob River, the basin of which has developed glaciation. Downstream, the Luchob River flows into the Varzob River, but its catchment area is low 
and has insignificant glaciation. One kilometer below the mouth of the Varzob River, a branch of the Elok River with a distance of about $100 \mathrm{~km}$ flows into the KR. The KR receives the last large tributary on the right - the Khonaqo River-which originates on the southern slope of the Gissar ridge. After the confluence of the Khonaqo River, the Kaofarnihon River turns to the south, flows in the intermontane valley of southern Tajikistan, and flows into the Amu Darya River [57].

The Kofarnihon River has a snow-glacial type of feeding. The respective values of the mean monthly precipitation and mean monthly runoff over the Kofarnihon River Basin varies from $5.50 \mathrm{~mm}$ to $119 \mathrm{~mm}$ and from $60 \mathrm{~m}^{3} / \mathrm{s}$ to $414 \mathrm{~m}^{3} / \mathrm{s}$ (Figure 2). On the rivers of the basin, the beginning of the flood season is timed in late March to early April. Seasonal snow plays the main role in the formation of high water; therefore, its duration is determined mainly by the water reserves in the snow. The peak of the flood period with the highest annual water discharge takes place in May-June. The main role in the formation of the flow of the KR belongs to solid precipitation. The main source of food for the rivers of the KRB is melted snow water. The largest share in the annual runoff is snow-fed, accounting for $60-70 \%$ of the annual runoff. Underground recharge makes up $20-25 \%$ of the annual runoff. The share of glacial recharge in the total runoff is in direct proportion to the degree of glaciation in the basin and the average height of the catchment area. The share of glacial runoff increases significantly during the ablation period (from July to September) and reaches $30-50 \%$. The share of glacial recharge in the river runoff of the region varies depending on the snowiness of the winter. In years with little snow, it increases since the tongues of glaciers are freed from seasonal snow much earlier than in heavy snow. In such years, the share of glacial runoff increases more than 1.5 times [58].

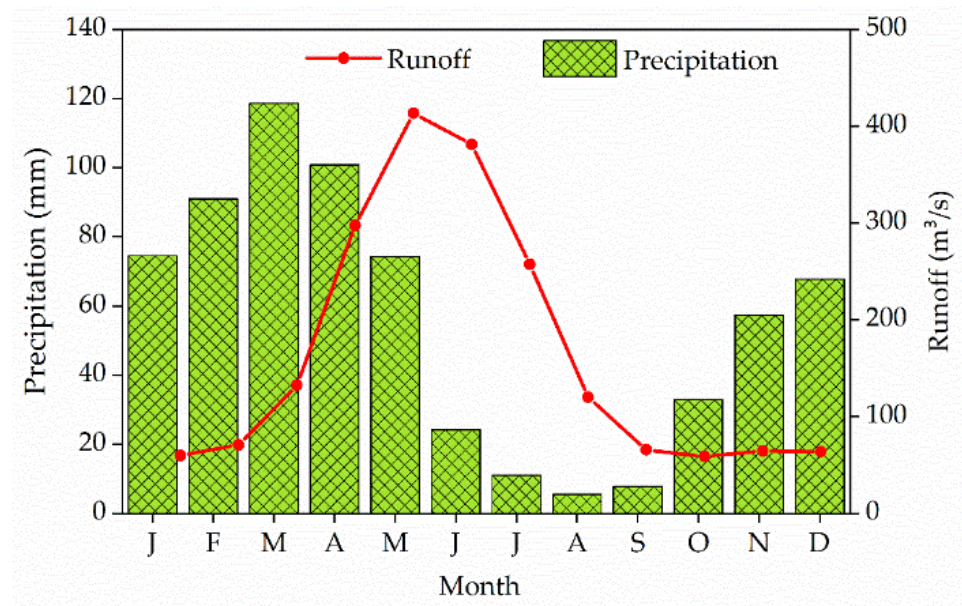

Figure 2. The mean monthly values of the runoff and mean monthly precipitation in the Kofarnihon River Basin, Central Asia.

\subsection{Data Source}

The climate and hydrological data include information on mean annual temperature, annual precipitation, and annual runoff over the Kofarnihon River Basin. The climate data were obtained for seven stations from the Agency of Hydrometeorology of the Committee for Environmental Protection under the Government of the Republic of Tajikistan (Table 1). The Ministry of Energy and Water Resources of the Republic of Tajikistan was supplied the hydrological data (Table 1). The accuracy of the climate data was compared with two other sources including (http:/ / www.pogodaiklimat.ru, accessed on 7 May 2021) and (http: / / snobear.colorado.edu/Markw /Geodata/geodata.html, accessed on 7 May 2021), which provide hydro-climatic data for Central Asian countries. In the downstream area of the Kofarnihon River Basin at the Tartki discharge station, roughly 6-year gaps in the annual runoff data were found, which were corrected with the linear interpolation method. The accuracy of the runoff data in the upstream region was associated with the data 
of OSHC "Barqi Tojik" (http:/ /www.barqitojik.tj/, accessed on 7 May 2021) where the company Open Stock Holding Company (OSHC) "Barqi Tojik" has its observational point for measuring the river runoff of the Varzob River. In this study, we used the PET data from the Climate Research Unit (CRU, TS v.4.02) between 1950 and 2016 [59]. The PET data from CRU has been correlated with the PET, which was determined using the five different methods including the Penman-Monteith (FAO 56 PM) [60], Hargreaves-Samani [61], Makkin [62], Pristley-Taylor [63], and Jensen-Haise [64]. It should be noted that for the correlation of the PET data, we used the daily maximum and minimum temperature from the measurement-based station of the upstream and downstream regions of the KRB in Central Asia. The results of the scatterplot show that the correlation of the PET from CRU is well correlated with the five above-mentioned methods. In addition, we found that the correlation in the downstream region slightly is better than correlation in the upstream region of the catchment. Similarly, previous studies show that the CRU dataset is comparatively authentic for use in Central Asia [65]. Figure 3 shows the correlation between the PET from CRU and five different methods in the upstream and downstream regions of the KRB.

Table 1. Location of the discharge and climate stations under consideration with coordinates.

\begin{tabular}{ccccc}
\hline WMO Nr & Climate Station & Latitude $\left({ }^{\circ} \mathbf{N}\right)$ & Longitude $\left({ }^{\circ} \mathbf{E}\right)$ & Elevation $(\mathbf{m})$ \\
\hline 38,719 & Anzob & 39.50 & 68.52 & 3373 \\
38,718 & Iskenderkul & 39.10 & 68.38 & 2204 \\
38,833 & Hushyori & 38.53 & 68.50 & 1361 \\
38,845 & Faizobod & 38.32 & 69.19 & 1215 \\
38,836 & Dushanbe & 38.35 & 68.44 & 800 \\
38,838 & Isambay & 38.3 & 68.21 & 563 \\
38,937 & Shaartuz & 36.58 & 68.20 & 378 \\
\hline \multirow{2}{*}{ WO Nr } & Discharge & Latitude $\left({ }^{\circ} \mathrm{N}\right)$ & Longitude $\left({ }^{\circ} \mathrm{E}\right)$ & Elevation $(\mathrm{m})$ \\
& station & 38.59 & 68.77 & 1295 \\
17,150 & Dahana & 37.78 & 68.18 & 419 \\
17,137 & Tartki & &
\end{tabular}

The climate of the area under consideration is characterized by sufficient moisture, moderately warm summers, and moderately severe snowy winters. The ruggedness of the relief and the diversity of heights determine the climatic differences of individual regions and vertical zoning. The altitude zone $1000-2500 \mathrm{~m}$ is characterized by moderately mild winters and warm summers and the altitudinal zone $2500-3000$ m by moderately mild winters and moderately warm summers. In areas above $3000 \mathrm{~m}$ above sea level, the weather is characterized by cold summers and moderately severe snowy winters [58].

The average annual air temperature ranges from $8{ }^{\circ} \mathrm{C}$ to $6{ }^{\circ} \mathrm{C}$ at an altitude of 2000-2500 $\mathrm{m}$ to $-1{ }^{\circ} \mathrm{C}$ at an altitude of $3000 \mathrm{~m}$. At the Anzob, the average annual air temperature is $-1.8^{\circ} \mathrm{C}$. In the Kofarnihon River Basin, the coldest month is January $\left(-12{ }^{\circ} \mathrm{C}\right)$ and the absolute minimum temperature reaches $-35^{\circ} \mathrm{C}$ to $-40^{\circ} \mathrm{C}$. The duration of the period with air temperature below $0{ }^{\circ} \mathrm{C}$ is $250-270$ days at altitudes of $3000-3500 \mathrm{~m}$ and 280-310 days at altitudes of 4000-4500 $\mathrm{m}$ [58].

At an altitude of more than $2000 \mathrm{~m}$, a stable snow cover forms in November and persists until May and at an altitude of more than $3000 \mathrm{~m}$ until June. The average (of the highest for the winter) height of the snow cover reaches $267 \mathrm{~cm}$. There is also a lot of snow on the passes, wherein some years its height reaches 2-2.5 $\mathrm{m}$ [58].

In Central Asia, Tajikistan is known as a predominantly mountainous landscape. Mountains occupied nearly $93 \%$ of Tajikistan's territory. For the water availability in the Central Asia, Tajikistan's glaciers play an important role. The high concentration of glaciers of Tajikistan provide nearly 70\% of the rivers in the Aral Sea Basin [56]. The economy is mainly supported by light industry, non-ferrous metallurgy, and agriculture in Tajikistan. The hydropower potential is big and according to the Ministry of Energy and 
Water Resources of the Republic of Tajikistan from the possible energy capacity around 5\% is used. Nearly $25 \%$ of the total Gross Domestic Product (GDP) comes from the agricultural sector and it is responsible for $70 \%$ of the employment in Tajikistan. The main crops are cotton, vegetables, cereals, melons, and fruits. The melting of glaciers in Kyrgyzstan and Tajikistan will have contrary influences on water presence in the downstream country such as Uzbekistan, where about $90 \%$ of the water intake is utilized in agriculture [66].
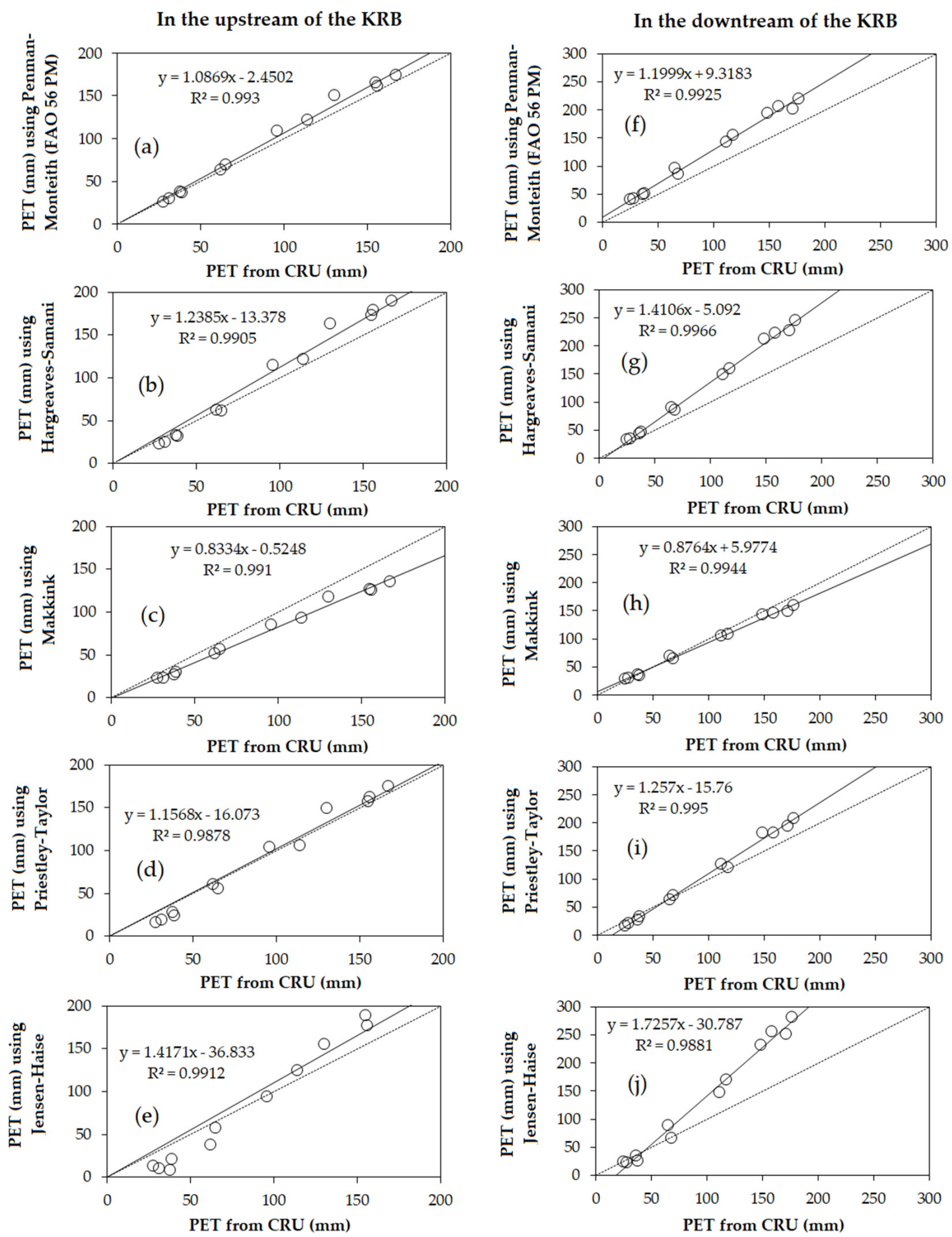

Figure 3. Monthly potential evapotranspiration (PET) in the upstream region (figures on the left side (a-e)) and monthly PET in the downstream region (figures on the right side $(\mathbf{f}-\mathbf{j})$ ) for 2000 at the Hushyori (in the upstream region) and Isambay (in the downstream region) climate stations in the Kofarnihon River Basin, Central Asia. 
According to the FAO AQUASTAT database (http:/ / www.fao.org/nr/water/aquastat/ data /, accessed on 7 May 2021) in Tajikistan annually $10.96 \mathrm{~km}^{3}$ of water is withdrawing for agriculture. Tajikistan's population is 9.2 million, with almost three-quarters of the country living in rural areas. In the last decade (2000-2010), the average annual water intake from surface sources was $9 \mathrm{~km}^{3}$ and about $2 \mathrm{~km}^{3}$ from underground [67]. Tajikistan annually consumes about $15-20 \%$ of the volume of water formed within its boundaries [67]. Irrigated agriculture consumes about $85 \%$ of the total amount of water taken, and household and drinking water supply consumes $4 \%$, industry consumes $4 \%$, fisheries consume $1 \%$, and other industries consume 6\% [68].

Reforms in the agricultural sector, a change in the structure and areas of crops, the growth of unused irrigated land, and irrigation systems failure has led to a decrease in water consumption by $10-15 \%$ compared to the Soviet period. Due to the failure to implement measures on irrigation systems, as a result, more than 60,000 hectares of irrigated land are not used annually. In Tajikistan, 4.8 million hectares are used for agriculture or 33\% of the total area of the country including 3.8 million hectares of natural pastures, about 850,000 hectares of arable land, and 138,000 hectares of perennial plantations. The lands of settlements occupy about 156,000 hectares and will continue to increase due to the expansion of the boundaries of settlements and the growth of the population. In terms of the provision of forest resources, Tajikistan ranks last among the countries of Central Asia $[67,68]$. The irrigated land change over the two last decades is shown in Table 2 [69].

Table 2. Variation of the irrigated lands in the recent years compared to the 1980s in Tajikistan, Central Asia.

\begin{tabular}{cccccccccccc}
\hline $\begin{array}{c}\text { Crop } \\
\text { Area } \backslash \text { Year }\end{array}$ & $\mathbf{1 9 8 0}$ & $\mathbf{1 9 9 9}$ & $\mathbf{2 0 0 5}$ & $\mathbf{2 0 0 7}$ & $\mathbf{2 0 1 0}$ & $\mathbf{2 0 1 2}$ & $\mathbf{2 0 1 3}$ & $\mathbf{2 0 1 4}$ & $\mathbf{2 0 1 5}$ & $\mathbf{2 0 1 6}$ & $\mathbf{2 0 1 7}$ \\
\hline Area $\left(10^{3} \mathrm{ha}\right)$ & 627.6 & 717.9 & 732.4 & 741.7 & 743.6 & 748.3 & 749.6 & 749.6 & 752.5 & 753.0 & 753.9 \\
Rate $(\%)$ & & 14.4 & 16.7 & 18.2 & 18.5 & 19.2 & 19.4 & 19.4 & 19.9 & 20.0 & 20.1 \\
\hline
\end{tabular}

The main sowing of crops in Tajikistan is shown in Figure 4. According to the results of sowing winter and spring crops in all categories of economic entities of the 2019 harvest, the sown area of crops amounted to 846,990 hectares. Of the total sown area, $45.3 \%$ are grain crops, $25.5 \%$ are industrial crops like cotton, $6.1 \%$ are potatoes, $7.9 \%$ are vegetables (including seeds), $2.6 \%$ are melons, and $12.6 \%$ are forage crops [68].

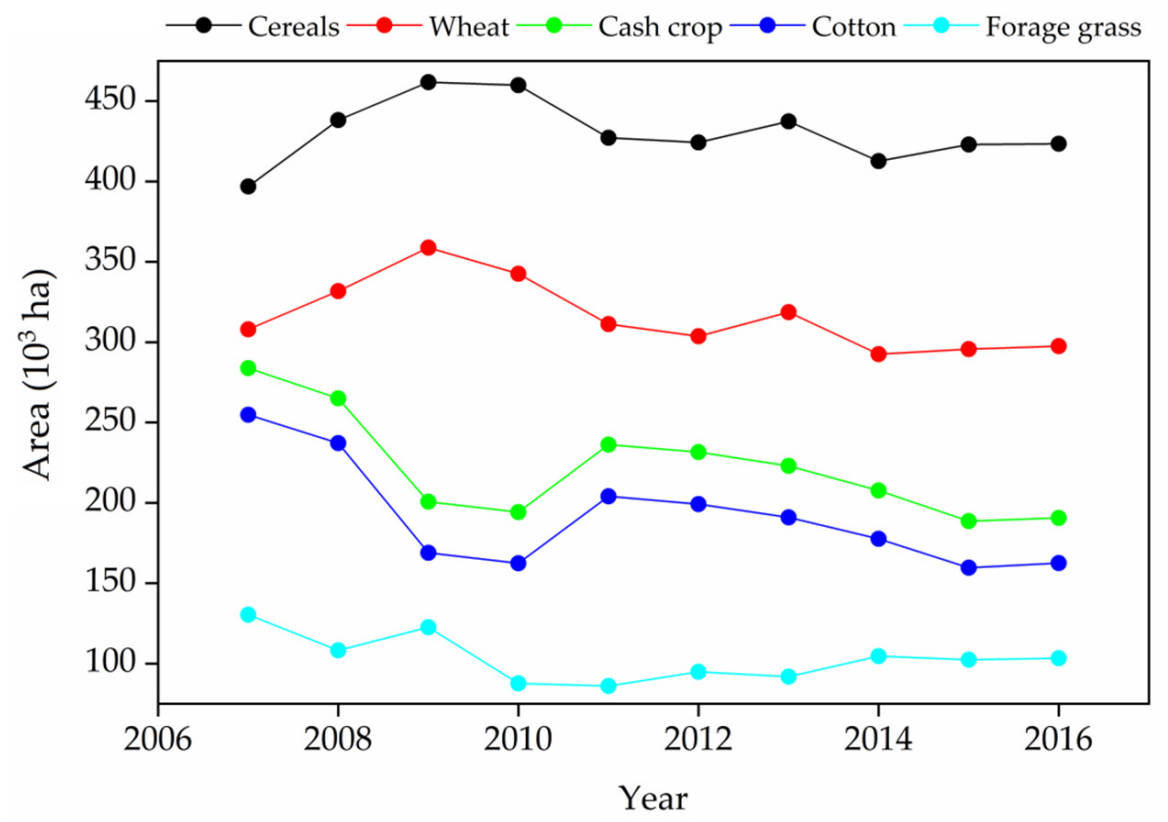

Figure 4. The dynamics of the main crop area in the last decade in Tajikistan, Central Asia. 
The total population of Tajikistan under the Soviet Union in 1950 was 1.5 million. Over the past 70 years, Tajikistan's population has grown by more than 6 times. The annual rate of natural growth is $2.3 \%$. Only one-fourth of Tajikistan's residents live in cities, making the country the least urbanized country in the region. In the KRB within Tajikistan's territory, there are several cities and districts located such as Dushanbe, Varzob, Hisor, Vahdat, Rudaki, Tursunzoda, Faizobod, Shahrinav, N. Khusrav, Qubodiyon, and Shaartuz where the population is growing year after year. The average population density is 55 individuals $/ \mathrm{km}^{2}$. The population growth rate is shown in Figure A1 (Appendix A) [67].

\section{Methodology}

\subsection{Mann-Kendall Trend Test}

The Mann-Kendall (MK) test is a non-parametric test for identifying the significance of trends in hydro-climatic data [70]. In this study, the MK test approach was applied to evaluate the trends of time series data (the annual runoff, annual precipitation, annual mean temperature, and annual PET during the 1950-2016 time period) in the Kofarnihon River Basin. Based on the linear regression the trend rate $m_{1}$ was identified using Equation (1).

$$
Y_{t}=m_{1} x_{t}+c_{o}
$$

where $x$ shows the runoff, precipitation, temperature, and PET at time $t$ (1950-2016). The significance of $m_{1}$ was verified by the $t$-test. The positive and negative values of $m_{1}$ indicates a growing and declining trend of PET, temperature, precipitation, and runoff in specific time series [71]. Yue and Wang [72] pointed out that the puissance of the trend depends on the sample size, magnitude of trend, the number of changes over a time series, and the adjusted significance level. Since $x_{j}$ and $x_{k}$ in time series $\mathrm{X}=\left[x_{1}, x_{2}, \ldots, x_{n}\right]$ are independent, by Equation (2), the MK test statistics $(S)$ and signs are determined as follows:

$$
\begin{gathered}
S=\sum_{k=1}^{n-1} \sum_{j=k+1}^{n} \operatorname{sgn}\left(x_{j}-x_{k}\right), \\
\operatorname{sgn}\left(X_{j}-X_{k}\right)=\left\{\begin{array}{c}
\text { if }\left(X_{j}-X_{k}\right)>0,+1 \\
\text { if }\left(X_{j}-X_{k}\right)=0,0 \\
\text { if }\left(X_{j}-X_{k}\right)<0,-1
\end{array}\right\}
\end{gathered}
$$

where $n$ is the number of the variable set, $x_{j}$ and $x_{k}$ are the sequential variables at times $j$ and $k$, and sgn is the sign function that takes on magnitudes of $-1,0$, and +1 . The subsequent value of $S$ shows growing or declining trends in hydro-climatic variable sets.

$$
\operatorname{Var}(\mathrm{S})=\frac{\mathrm{n}(\mathrm{n}-1)(2 \mathrm{n}+5)-\sum_{\mathrm{k}=1}^{\mathrm{p}} \mathrm{t}_{\mathrm{k}}\left(\mathrm{t}_{\mathrm{k}}-1\right)\left(2 \mathrm{t}_{\mathrm{k}}+5\right)}{18}
$$

The tied group's number is shown by the $p$-value, and the $t_{k}$ is the number of measured variability in the $k$ th group. After the variance $\operatorname{Var}(\mathrm{S})$ is calculated from Equation (4), the (STS) standardized test statistic $\left(Z_{S}\right)$ is determined by Equation (5).

$$
Z_{S}=\left\{\begin{array}{c}
\frac{S-1}{\sqrt{\operatorname{Var}(\mathrm{S})}}, S>0 \\
0, S=0 \\
\frac{\mathrm{S}+1}{\sqrt{\operatorname{Var}(\mathrm{S})}}, S<0
\end{array}\right\},
$$

where $Z_{S}$ demonstrates the significance of the trend. The STS is employed to test the null hypothesis, $H_{0}$ if $Z_{s}>Z_{\alpha / 2}$, and $\alpha$ indicates the confidence level. The trend is significant at the $90 \%(\alpha=0.1), 95 \%(\alpha=0.05)$, and $99 \%(\alpha=0.01)$ confidence level if $Z_{s}>1.45, Z_{s}>1.96$, and $Z_{s}>2.56$. At the $1 \%, 5 \%$, and $10 \%$ significance degree, the null hypothesis of no trend is rejected if $Z_{s}>1.45, Z_{s}>1.96$, and $Z_{s}>2.56$, respectively. In Appendix $A$, the comprehensive description of the modified Mann-Kendall test can be found. 


\subsection{Sen's Slope Estimator}

Sen (1998) developed the non-parametric approach for estimating the slope of trend in the sample of $N$ pairs of data [73]:

$$
\mathcal{Q}_{i}=\left(\frac{x_{j}-x_{k}}{j-k}\right) / \mathrm{d} t \text { for } i=1, \ldots, N
$$

where $x_{j}$ and $x_{k}$ show the data values at times $j$ and $k(j>k)$, respectively. $\mathrm{d} t$ is the chosen time interval.

If there is only one datum in each time period, then $N=\frac{n(n-1)}{2}$, where $n$ is the number of time periods. Otherwise, $N<\frac{n(n-n)}{2}$, where $n$ is the total number of observations.

The median of the " $n$ " values of $N$ values of $\mathcal{Q}$ is Sen's estimator of slope. A positive value of $\mathcal{Q}$ shows an increasing trend, whereas a negative value shows a decreasing trend in the climatic time series data. The slope $(\mathcal{Q})$ of the " $n$ " values were sorted from smallest to the largest and the Sen's estimator can be evaluated using Equation (7):

$$
\text { Sen'sestimator }=\mathcal{Q}_{\frac{n+1}{2}} \text { if } n \text { is odd, } \frac{1}{2}\left[\mathcal{Q}_{\frac{n}{2}}+\mathcal{Q}_{\frac{n+1}{2}}\right] \text { if } n \text { is even. }
$$

where the sign of $\mathcal{Q}_{\text {med }}$ show the data trend pattern, whereas its value shows the steepness of the trend.

\subsection{Change Point Detection}

To determine a single change point in runoff, precipitation, temperature, and PET time series with a consistent variable, the Pettitt test [74] is used. Generally, if an adjacent change point existing in a series, the maximum value $\mathrm{K}_{\mathrm{T}}$ will be identified as the change point. Its statistic $\mathrm{K}_{\mathrm{T}}$ and the associated probabilities used in significance testing are given as

$$
\begin{gathered}
\mathrm{K}_{\mathrm{T}}=\max \left|\mathrm{U}_{\mathrm{t}, \mathrm{T}}\right| \\
\mathrm{U}_{\mathrm{t}, \mathrm{T}}=\sum_{\mathrm{i}=1}^{\mathrm{t}} \sum_{\mathrm{j}=\mathrm{t}+1}^{\mathrm{T}} \operatorname{sgn}\left(\mathrm{X}_{\mathrm{i}}+\mathrm{X}_{\mathrm{j}}\right) \quad(\mathrm{t}=1, \ldots, \mathrm{n})
\end{gathered}
$$

If $\left|U_{t, T}\right|$ growths with time $t$, this indicates that the order does not have a change point over the year in long-term datasets; conversely, if $\left|\mathrm{U}_{\mathrm{t}, \mathrm{T}}\right|$ indicates a decreasing trend compared to time $t$, this indicates that a change point happened in the series. The change point of the series is situated at $\mathrm{K}_{\mathrm{T}}$, which showed that the statistic is significant. The significance probability of $\mathrm{K}_{\mathrm{T}}$ is approximated for $\mathrm{p} \leq 0.05$ with

$$
\mathrm{p}=2 \exp \left(\frac{-6 \mathrm{~K}_{\mathrm{T}}^{2}}{\mathrm{~T}^{3}+\mathrm{T}^{2}}\right)
$$

\subsection{Double Cumulative Curve Method}

The double cumulative curve (DCC) is the graph of the accumulated data of one variable contrary to the accumulated data of another associated variable for a simultaneous period [75]. Based on the trend and change point analysis, the long-term data of runoff can be separated into the prior impacted period and the post impacted period. In this study, a DCC method along with the linear regression lines was applied to determine the change of runoff in the prior impacted period and in the post impacted period, as well as DCC, which demonstrated the confirmation of the change point that was found by Pettitt's test. The change point in the variables' cumulative curves is caused by variations in the relation between the variables considered. For the consistent demonstration of annual precipitation and runoff data, the DCC method can be used. This method recently became a useful tool for determining changes in the hydrological regime as a result of anthropogenic activities [76]. Changed runoff or precipitation characteristics can be determined from the 
gradient of the curve derived from the straight line DCC. The relative changes in runoff over the post impacted period can be estimated using equations adapted to the DCC in the prior impacted period, which can be shown as:

$$
S_{c}=\alpha \sum P+b
$$

where $S_{c}$ is the computed cumulative runoff, $\sum P$ is the measuring station of the cumulative precipitation, and $\alpha$ and $b$ are parameters examined by using the linear regression lines in the DCC in the prior impacted period. Thus, based on the division in the post impacted period and the prior impacted period, the impacts of climate variability and anthropogenic activities on runoff were evaluated applying a hydrological simulation, as presented below.

\subsection{The Climate Elasticity Method}

To quantitatively analyze the impacts of climate variability and human activities on runoff, the water balance equation based Budyko model [77] was applied to the hydroclimatic series during the prior impacted period and post impacted period, which was identified by Pettitt's test.

The theory of a water-based balance provides a basis for analyzing hydrological behavior in a basin and shows interconnections of $E, P$, and $R$ :

$$
R=P-E-\Delta S .
$$

where $R$ and $P$ indicate runoff and precipitation, $E$ is actual evapotranspiration, $\Delta S$ is the soil moisture content, and $\Delta S$ can be assumed to be zero for a long period of time series (i.e., ten years or more).

For a given basin, we assume that a change in average annual runoff can be evaluated as:

$$
\Delta R=R_{o b s, i}-R_{o b s, b}
$$

where $\Delta R$ shows the total change in an average annual runoff, $R_{o b s, i}$ shows the measured average annual runoff during the post impacted period, and $R_{o b s, b}$ shows the average annual runoff during the prior impacted period.

In the current analysis, the climate elasticity method has been used to identify the influence of climate variability and human intervention on runoff. It can be assumed that the overall variation in runoff can be associated with climate variability and human intervention, which can be described as: [19]:

$$
\Delta R=\Delta R_{\text {clim }}+\Delta R_{\text {hum }}
$$

where $\Delta R$ is the mean annual runoff of measured recorded variability, $\Delta R_{\text {clim }}$ is the variation in mean annual runoff in consequence of climate change, and $\Delta R_{h u m}$ is the variation in average annual runoff due to human intervention. Once $\Delta R_{\text {clim }}$ is determined, $\Delta R_{\text {hum }}$ can be found by employing Equation (14).

The comparative contribution of climate change and human activities to runoff can be stated as Equations (15) and (16):

$$
\begin{aligned}
& \text { Rate }_{\text {clim }}=\frac{\Delta R_{\text {clim }}}{\Delta R} \times 100 \% \\
& \text { Rate }_{\text {hum }}=\frac{\Delta R_{\text {hum }}}{\Delta R} \times 100 \%
\end{aligned}
$$

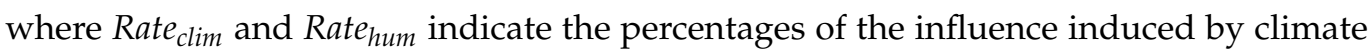
variability and the human intervention on the runoff variation.

The sensitivity of runoff to climate variability can be determined by applying the climate elasticity method. Perturbations of potential evapotranspiration (PET) and precipi- 
tation can induce an alteration in water balance at the reference analysis. Therefore, the total variation in the average annual runoff can be determined with Equation (17):

$$
\Delta R_{\text {clim }}=\varepsilon_{P} \frac{R}{P} \Delta P+\varepsilon_{P E T} \frac{R}{P E T} \Delta P E T,
$$

where $\triangle P E T$ is the change in mean annual potential evapotranspiration and $\triangle P$ is the change in mean annual precipitation, respectively; for the sensitivity examination, two parameters, $\varepsilon_{P E T}$ and $\varepsilon_{P}\left(\varepsilon_{P E T}\right.$ and $\varepsilon_{P}$ are the elastic coefficients of potential evapotranspiration and precipitation), were described:

$$
\begin{gathered}
\varepsilon_{P}=1+\frac{\phi F^{\prime}(\phi)}{1-F(\phi)} \\
\varepsilon_{P E T}=-\frac{\phi F^{\prime}(\phi)}{1-F(\phi)} \\
\varepsilon_{P}+\varepsilon_{P E T}=1
\end{gathered}
$$

where $\phi$ indicates the dryness coefficient, provided by $\phi=P E T / P$ (the potential evapotranspiration is PET and $P$ is precipitation). Equations (21) and (22) can be described as follows:

$$
\begin{gathered}
F(\phi)=\frac{1+\omega \phi}{1+\omega \phi+\frac{1}{\phi}} \\
F^{\prime}(\phi)=\frac{1+2 \frac{\omega}{\phi}-1+\frac{1}{\phi^{2}}}{\left(1+\omega \phi+\frac{1}{\phi}\right)^{2}}
\end{gathered}
$$

Here, $F(\phi)$ is called the Budyko curve equation [52], where $\omega$ shows the plant-available water capacity coefficient connected to vegetation category [78], which vary from 0.01 to 2.0. Using Equation (23), this coefficient can be examined. The Equation (23) was developed by Zhang based on the Budyko hypothesis to simulate the total evaporation at the watershed scale [78]:

$$
\frac{E}{P}=\frac{1+\frac{\omega \times P E T}{P}}{1+\frac{\omega \times P E T}{P}+\frac{P}{P E T}}
$$

where the values indicate evapotranspiration $E$, potential evapotranspiration $(P E T)$, and precipitation $(P)$ during a period. In this study, the overview of the used hydro-climatic datasets with applied methodologies is shown as a proposed framework in Figure 5. 


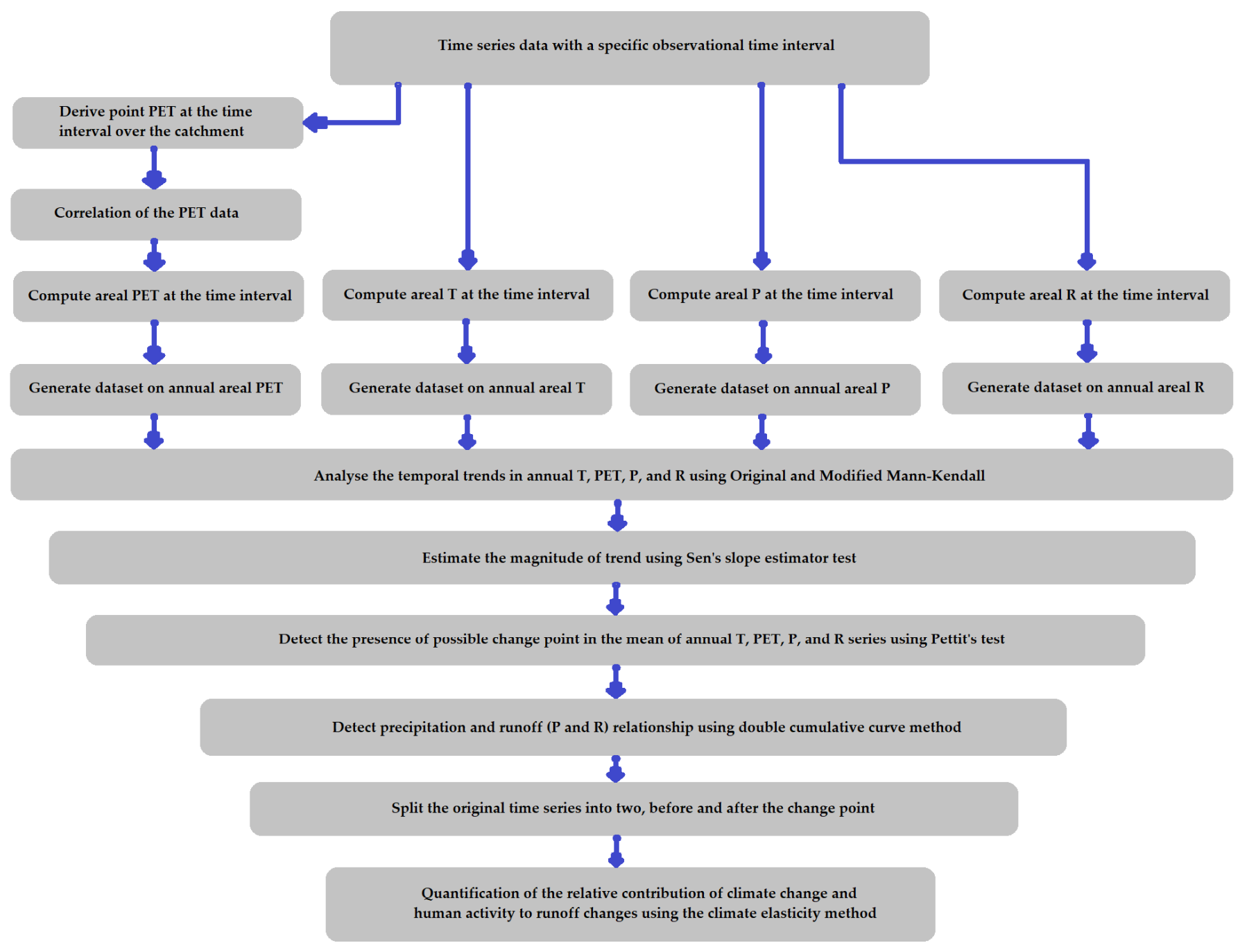

Figure 5. The proposed framework. T, PET, P, and R, respectively, are temperature, potential evapotranspiration, precipitation, and runoff.

\section{Results}

4.1. Trend and Change Point Analysis of the Temperature, Precipitation and Potential Evapotranspiration Series

Following the long-term measurement-based hydro-climatic data in the upstream and downstream regions of the ungauged Kofarnihon River Basin, the trends and magnitudinal changes in temperature, precipitation, potential evapotranspiration were computed by utilizing the non-parametric original Mann-Kendall test, modified Mann-Kendall test, and Sen's slope estimator. Besides, the present work employed Pettitt's test to determine the variations during the 1950-2016 time period. In this study, the accessibility of measurementbased data and its application in the regional study were important to obtain results of the hydro-climatic variation and impacts of the climate alteration on water regimes in recent decades in the KRB. The changes in temperature, potential evapotranspiration, and precipitation during the 1950-2016 time period in the downstream and upstream regions of the KRB are shown in Figure 6.

Our results revealed an increasing trend in annual temperature in the downstream region at a rate of $0.023^{\circ} \mathrm{C} /$ year and in the upstream region at a rate of $0.0108{ }^{\circ} \mathrm{C} /$ year. The decreasing trend of annual precipitation was observed at a rate from $-0.0124 \mathrm{~mm} /$ year to $-0.2134 \mathrm{~mm} /$ year in both downstream and upstream regions of KRB. However, the increas- 
ing trend in the annual potential evapotranspiration was found at a rate of $0.4142 \mathrm{~mm} / \mathrm{year}$ in the downstream and a rate of $0.3899 \mathrm{~mm} /$ year in the upstream regions of the catchment.
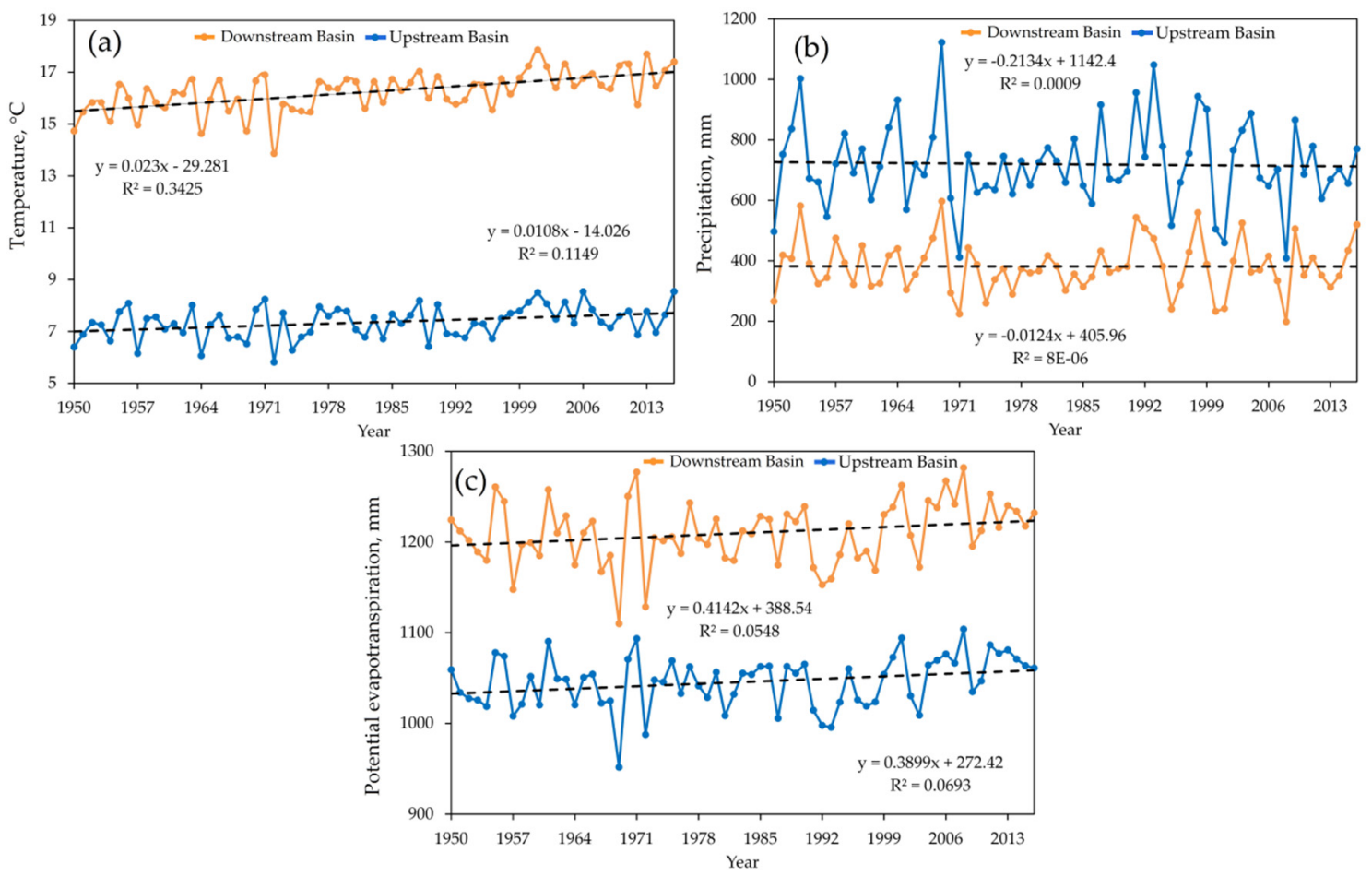

Figure 6. (a) The trend of annual average temperature; (b) the trend of annual precipitation; and (c) the trend of annual potential evapotranspiration during the 1950-2016 time period.

The results of the annual temperature, annual precipitation, and annual potential evapotranspiration during the 1950-2016 time period are shown in Table 3. Based on the modified MK test, the annual temperature indicated a significant increasing trend in the upstream and downstream regions of the KRB. The annual precipitation showed a decreasing trend; hence, either original or modified MK tests showed that the decreasing trend is not statistically significant in both upstream and downstream regions of the catchment. The modified MK test showed a significant increasing trend in the annual potential evapotranspiration in the upstream and downstream parts of the KRB over the 1950-2016 time period. The increasing temperature in this study area indicates that this region faces climate variability. The constantly increasing temperature causes increasing evapotranspiration in the catchment. In our previous study, we demonstrated the seasonal trend analysis of temperature, precipitation, and streamflow upstream of the KRB. Those results were compared with the fifth assessment report (AR5) of the Intergovernmental Panel on Climate Change (IPCC) [79].

The change point examination of hydro-climatic factors was investigated by Pettitt's test. The change point for the annual mean temperature occurred in the downstream in 1976 and in the upstream regions in 1996. Our results of the change points occurrences for the temperature in both the downstream and upstream parts are in line with the study by Rakhimova et al. [30] and Bissenbayeva et al. [31] in Central Asia. For the precipitation, the change point was detected in 1969 while for potential evapotranspiration it was in 1998 in both the upstream and the downstream parts of the KRB during 1950-2016. Pettitt's test results showed that in this mountainous region, especially in the low-altitude areas of the catchment, the earlier changes were detected in temperature. This variability could be associated with the earlier impacts of climate variation on the low-altitude regions of the mountainous Kofarnihon River Basin in Central Asia. 
Table 3. The identification of the change point and trend $(\mathrm{Z})$ and Sen's slope investigation for temperature $(\mathrm{T})$, potential evapotranspiration (PET), and precipitation (P) during the period of 1950-2016.

\begin{tabular}{|c|c|c|c|c|c|c|}
\hline \multirow{3}{*}{ Factor } & \multicolumn{6}{|c|}{ Upstream Basin } \\
\hline & Original MK Test & Modified MK Test & \multirow{2}{*}{$p$-Value } & \multirow{2}{*}{ Slope } & \multirow{2}{*}{$\begin{array}{c}\text { Significance } \\
\text { Based on the Modified MK Test }\end{array}$} & \multirow{2}{*}{$\begin{array}{l}\text { Change Point } \\
\text { (Year) }\end{array}$} \\
\hline & Z-Value & Z-Value & & & & \\
\hline Temperature & 2.576 & 8.131 & 0.000 & 0.009 & $* * *$ & 1996 \\
\hline Precipitation & -0.065 & -0.223 & 0.823 & 0.073 & NS & 1969 \\
\hline PET & 2.414 & 4.543 & 0.000 & 0.418 & $* * *$ & 1998 \\
\hline \multirow{3}{*}{ Factor } & \multicolumn{6}{|c|}{ Downstream Basin } \\
\hline & Original MK Test & Modified MK Test & \multirow{2}{*}{$p$-Value } & \multirow{2}{*}{ Slope } & \multirow{2}{*}{$\begin{array}{c}\text { Significance } \\
\text { Based on the Modified MK Test }\end{array}$} & \multirow{2}{*}{$\begin{array}{l}\text { Change Point } \\
\text { (Year) }\end{array}$} \\
\hline & Z-Value & Z-Value & & & & \\
\hline Temperature & 4.921 & 17.252 & 0.000 & 0.023 & $* * *$ & 1976 \\
\hline Precipitation & -0.022 & -0.076 & 0.940 & 0.015 & NS & 1969 \\
\hline PET & 1.927 & 3.760 & 0.000 & 0.438 & $* * *$ & 1998 \\
\hline
\end{tabular}

The significance levels tested are ${ }^{* * *}$ for $p<0.001$, NS for $p \geq 0.1$.

\subsection{Identification of Change Point and Trend Test of Runoff}

The trend test of runoff with the long-term data was applied in the downstream and upstream areas of the Kofarnihon River Basin (Figure 7). In the upstream regions, the average annual runoff varied from $640.52 \mathrm{~mm}$ to $1571.21 \mathrm{~mm}$ during the 1950-2016 time period and the mean annual was $1010.35 \mathrm{~mm}$. In the downstream areas, the range of mean annual runoff was around $324.62 \mathrm{~mm}$ to $815.86 \mathrm{~mm}$ with an annual mean of $583.16 \mathrm{~mm}$.
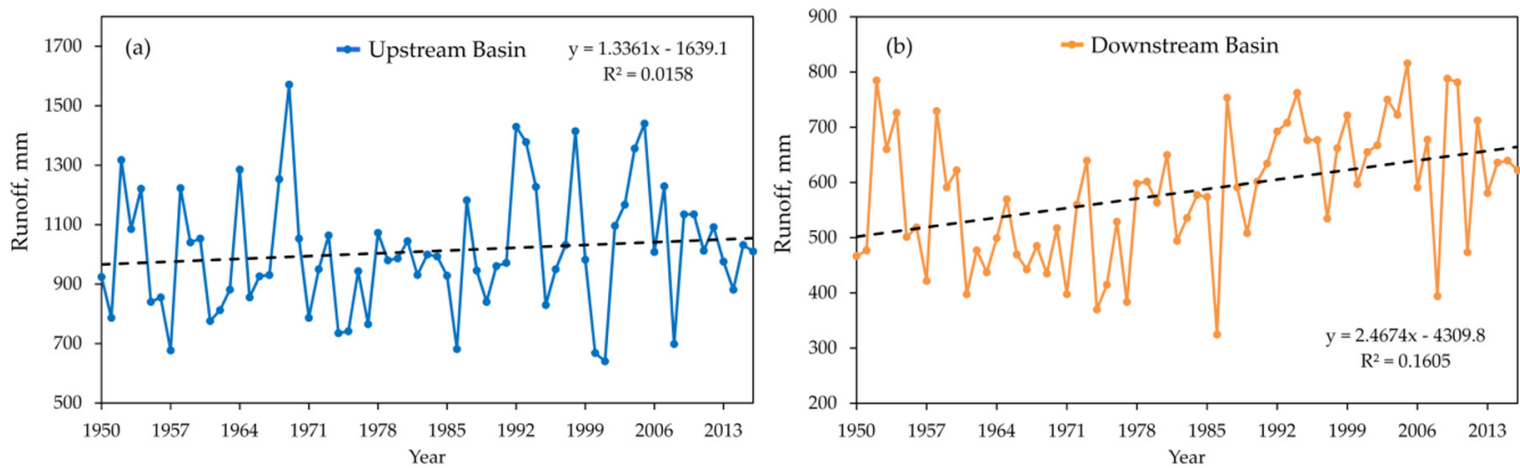

Figure 7. The trend of annual runoff during the period of 1950-2016 in the (a) upstream and (b) downstream of the Kofarnihon River Basin, Central Asia.

The result of the modified MK test showed a significant increasing trend in the upper and lower reaches of the catchment, as shown in Table 4. In the upstream and downstream regions, the statistical values of $Z$ based on the modified MK test were 3.561 and 5.307, respectively. The annual runoff showed an increasing trend in the upstream and downstream regions as $1.3361 \mathrm{~mm} /$ year and $2.4674 \mathrm{~mm} /$ year. During the last 66 years, the runoff has been increasing in the Kofarnihon River in Central Asia.

Table 4. Identification of change points and trend (Z), Sen's slope for runoff in the downstream (Tartki Station) and upstream (Dahana Station) of the Kofarnihon River Basin in Central Asia over the 1950-2016 time period.

\begin{tabular}{|c|c|c|c|c|c|c|c|}
\hline \multirow{2}{*}{$\begin{array}{l}\text { Hydrological } \\
\text { Station }\end{array}$} & $\begin{array}{c}\text { Original MK } \\
\text { Test }\end{array}$ & $\begin{array}{c}\text { Modified MK } \\
\text { Test }\end{array}$ & \multirow[t]{2}{*}{$\begin{array}{l}\text { Change Rate } \\
(\mathrm{mm} / 10 \mathrm{a})\end{array}$} & \multirow[t]{2}{*}{$p$-Value } & \multirow[t]{2}{*}{ Slope } & \multirow{2}{*}{$\begin{array}{c}\text { Significance } \\
\text { Based on the Modified } \\
\text { MK Test }\end{array}$} & \multirow[t]{2}{*}{$\begin{array}{c}\text { Change Point } \\
\text { (Year) }\end{array}$} \\
\hline & Z-Value & Z-Value & & & & & \\
\hline $\begin{array}{c}\text { Tartki } \\
\text { (Downstream) }\end{array}$ & 3.561 & 5.307 & 2.467 & 0.000 & 3.038 & $* * *$ & 1991 \\
\hline $\begin{array}{c}\text { Dahana } \\
\text { (Upstream) }\end{array}$ & 1.445 & 4.471 & 1.336 & 0.000 & 1.804 & $* * *$ & 1986 \\
\hline
\end{tabular}


Climate change is an essential factor in runoff variability. Uneven allocation of temperature, evaporation, and precipitation alteration can impact the temporal and spatial characteristics of water resources. In addition, continuous variations in the climate and land use might impact natural runoff. To understand the magnitude and change point in the annual runoff series, this study used the Pettitt's test and Sen's slope estimator. The analysis based on Pettitt's test revealed that for the annual mean runoff, a change point in the upstream region occurred in 1986 while downstream of the catchment, it occurred in 1991 as shown in Table 4. The result of Pettitt's test in the upstream region is confirmed by the study of Bissenbayeva et al. [31] who also found a change point in 1991 for the Arys River Basin in Central Asia. Likewise, the result in the upstream region of the KRB is confirmed by the study by Xue et al. in the Tarim River Basin in Central Asia [6].

The mean and standard deviation, along with the coefficient of variations of the annual runoff in the prior impacted and post impacted periods were analyzed (Table 5). For the upstream region of the catchment, the mean annual runoff of the available years in the prior impacted period (1950-1986) was $972.23 \mathrm{~mm}$ with about $8.76 \%$, while annual runoff changes occurred in the post impacted period (1987-2016). For the downstream region, annual runoff changed from $536.47 \mathrm{~mm}$ in the available years of the prior impacted period (1950-1991) to $661.60 \mathrm{~mm}$ in the post impacted period (1992-2016). The coefficient of variation in annual runoff increased by $2.20 \%$ in the upstream region (1987-2016) but decreased by $-26.90 \%$ in the downstream region (1992-2016) of the catchment in the post impacted periods. This statistical analysis between the two periods showed that annual runoff in the upstream and downstream regions increased due to climate change.

Table 5. Statistical analysis of the annual runoff series between the prior impacted period and post impacted period in the Kofarnihon River Basin in Central Asia.

\begin{tabular}{|c|c|c|c|c|c|c|c|}
\hline \multirow[b]{2}{*}{ Regions } & \multicolumn{3}{|c|}{ Prior Impacted Period } & \multicolumn{3}{|c|}{ Post Impacted Period } & \multirow[b]{2}{*}{$\begin{array}{c}\text { Change } \\
(\%)\end{array}$} \\
\hline & $\begin{array}{l}\text { Mean } \\
(\mathrm{mm})\end{array}$ & $\mathrm{SD}(\mathrm{mm})$ & CV & $\begin{array}{l}\text { Mean } \\
(\mathrm{mm})\end{array}$ & $\mathrm{SD}(\mathrm{mm})$ & $\mathrm{CV}$ & \\
\hline Upstream & 972.23 & 194.11 & 0.20 & 1057.36 & 215.74 & 0.20 & 8.76 \\
\hline Downstream & 536.47 & 107.95 & 0.20 & 661.60 & 97.32 & 0.15 & 23.32 \\
\hline
\end{tabular}

Note: $\mathrm{CV}$ = coefficient of variation; $\mathrm{SD}$ = standard deviation.

Besides, the precipitation-runoff double cumulative curve (DCC) method was applied to detect the change point in the mean annual runoff series in the upstream and downstream regions of the KRB. The result of the cumulative annual runoff and cumulative annual precipitation is shown in Figure 8. The previous studies confirmed that the DCC method has multiple change points and assumes that the change point might have resulted from the climate variability and as well as from human activities $[14,80]$. Our study shows that the change point occurred in 2004 in the upstream region, while in the downstream region, it occurred in 1991. The runoff and precipitation had a fairly homogeneous trend before 2004 in the upstream region, and before 1991 in the downstream region. This uniform pattern explains the relationship between cumulative annual runoff and precipitation with two nearly straight lines in various slopes, which also describe the character of the runoff as changing after 2004 and 1991 in the upstream and downstream regions, respectively (Figure 8). Therefore, the regression line shows the characteristics of the Kofarnihon River runoff under natural conditions but changed after 1991. According to the DCC, the period before 2004 and 1991 can be considered as a natural period without human disturbances [14,81] or climate change [80,81] impacts and the period of 1950-2003 and 1992-2016 can be considered as the impacted period.

Further, for the period of the study, runoff was split into the baseline measure period (1950-1991) during which the impact of climate change and anthropogenic activities on runoff was negligibly influenced; and the change period (1992-2016) during which the increase in climate variation and human intervention caused an evident disturbance of the runoff for the downstream areas. Consequently, the post impacted period was divided into 
five sub-periods: 1992-1996, 1997-2001, 2002-2006, 2007-2011, and 2012-2016, respectively. The result of the DC compared to Pettitt's test showed a different year of the change point for the upstream region. It might be assumed that the change point due to climate change occurred in 1986 based on Pettitt's test and the human intervention occurred in 2004 based on the DCC results. A potential case for the change might be that runoff was influenced by melting snow and frozen soil in the upstream region, which was vulnerable to climate variability, whereas the downstream region was more affected by the anthropogenic factor. In the long-term, these variations in annual runoff, potential evapotranspiration, and precipitation can have serious consequences on the ecological balance of wetlands and sustainable agricultural development.
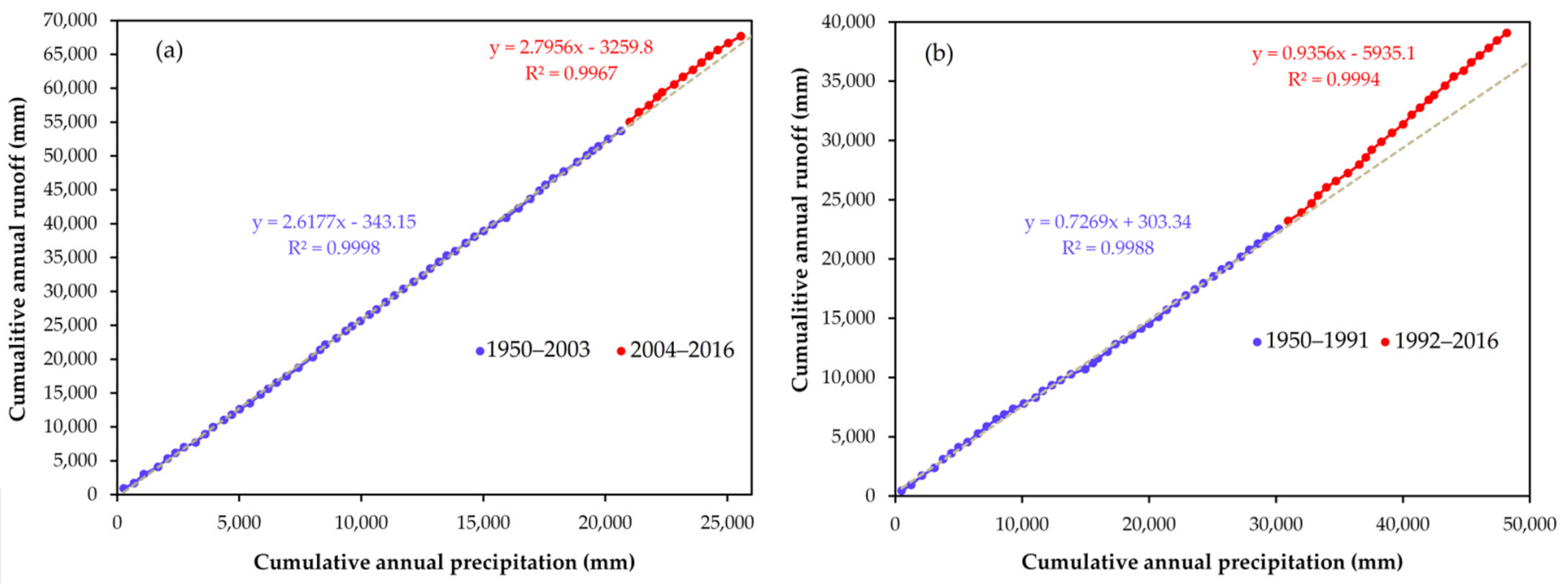

Figure 8. The double cumulative curve (DCC) of the annual runoff and precipitation in the (a) upstream region and (b) downstream region of the Kofarnihon River Basin in Central Asia.

\subsection{Changes in Runoff Regime}

The inter-annual variability of runoff is controlled by the seasonal cycle of precipitation, temperature, and snowmelt in the upper part of the catchment. As shown in Figure 9a, there have been changes in inter-annual variability of runoff in the catchment, with enlargements in mean monthly runoff in the period 1992-2016. The relatively high enlargements in runoff were greatest in May, June, and July and were unchanged in September, December, and January, while a slight reduction was observed in October. Runoff in the upper part of the catchment indicated seasonal patterns as a result of seasonality in the snowmelt, glacier melt, and precipitation. As a result of snowmelt, large runoff and flood occurs in spring. The flow duration curve shows the graphical view of the overall variability attributed to runoff and it is the complement of the cumulative distribution function on monthly runoff. Figure $9 \mathrm{~b}$ presents the monthly flow duration curve for the prior impacted period and post impacted period and relative increases in the monthly runoff with the same percentile. The changes in the high runoff index (Q5) and median runoff index (Q50) showed a slightly increasing tendency compared to the low runoff index (Q95) in the catchment based on the relationship between the two periods. The result of the flow duration curve method showed that the high and median runoffs increased by about $9.61 \%$ and $27.26 \%$, whereas the low flow decreased by about $-2.70 \%$. Increased high runoff implies a potential risk of flooding, which may happen in spring, while decreased low runoff implies a potential drought in the Kofarnihon River Basin. 

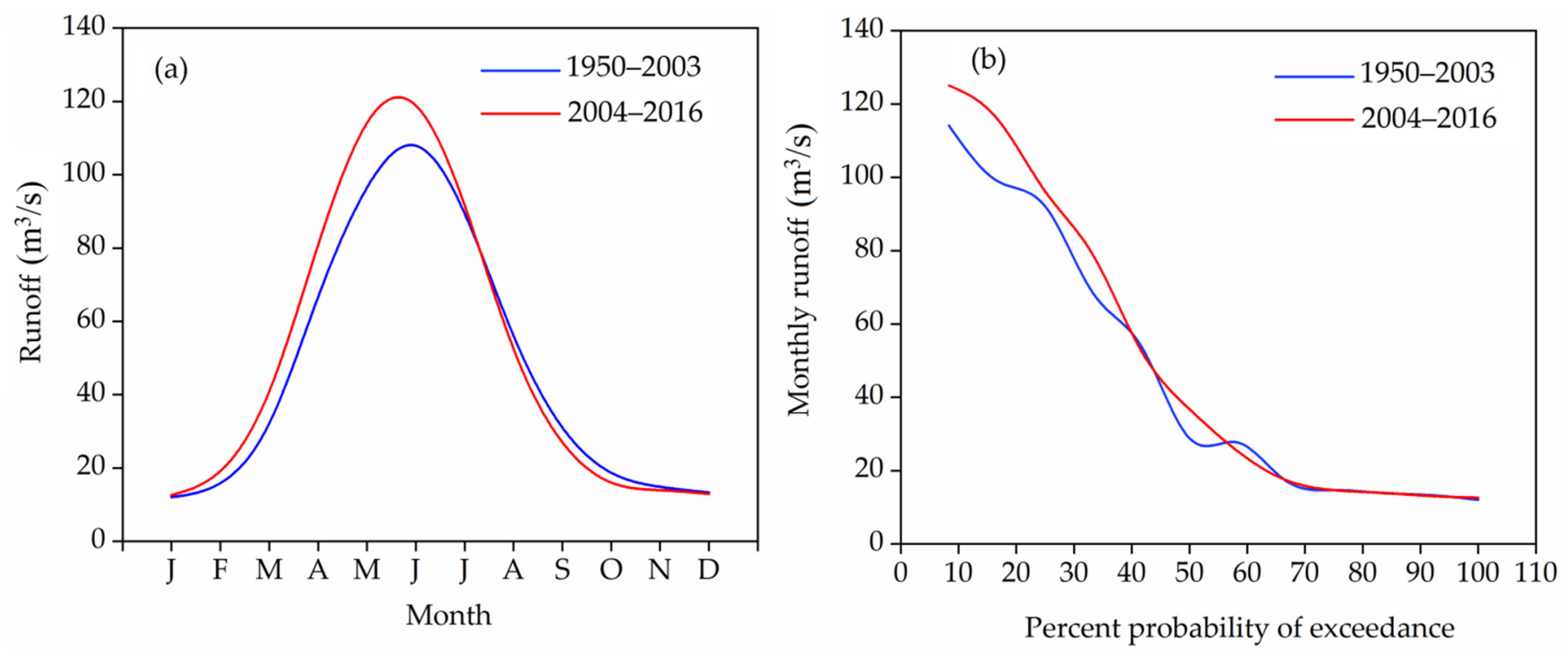

Figure 9. (a) Mean monthly runoff for the prior impacted period (1950-2003) and post impacted period (2004-2016) and (b) changes in flow duration curve between the prior impacted period and post impacted period in the upstream of the Kofarnihon River Basin.

\subsection{Effects of Climate Change and Anthropogenic Intervention on Runoff}

Identifying the elasticity of runoff to climate change remains a complex issue in hydrology due to the joint assessment between hydrological soil conductivity, soil waterholding capacity, climate, and land-use change $[19,82]$. To represent the interaction between inter water and heat limitation to runoff, it is possible to present the series data of potential evaporation, precipitation, and aridity index, which can be utilized to assess the effect of climate change on runoff. In the upstream areas of the KRB, there are many small and medium-size glaciers located [58], and the Kofarnihon River is a snowmelt fed and glacierfed type of river. It is essential to note that in this river basin, except for precipitation, runoff is also impacted by evapotranspiration, soil thawing, and freezing processes and ice-snow melting. The movements of the runoff are mostly the outcome of the hydrological processes, which depend on features such as the impact of climate change and human intervention [14].

In this study, based on the long-term hydro-climatic data, the climate elasticity method was applied to identify the influence of climate change and human disturbances on runoff in the upstream and downstream regions of the Kofarnihgon River Basin. To figure out the further influence of anthropogenic intervention in the post impacted period, six pairs for upstream and five pairs for downstream of observed runoff under an approximately equal quantity of potential evapotranspiration and precipitation are shown in Table 6. The prior impacted period for the upstream was arranged from 1950 to 1986 and for the downstream was arranged between 1950 and 1991. The post impacted period, which assumed the impacts of climate change and human activities, was arranged from 1987 to 2016 for the upstream and between 1992 and 2016 for the downstream of the KRB. Therefore, the runoff variations in every six-year period from the post impacted period 1950-1986 and 1992-2016 are compared with the prior impacted period 1987-2016 and 1950-1991.

In the upstream and downstream regions of the KRB, the total changes in runoff, precipitation, and potential evapotranspiration are $86.14 \mathrm{~mm}$ and $46.69 \mathrm{~mm}, 16.14 \mathrm{~mm}$ and $-0.32 \mathrm{~mm}$, and $8.70 \mathrm{~mm}$ and $8.05 \mathrm{~mm}$, respectively for the period 1987-2016 and 1992-2016 compared to the period of 1950-1986 and 1950-1991.

The variation in runoff induced by anthropogenic intervention is $-13.51 \mathrm{~mm}(12.04 \%)$ in the upstream region during 1987-2016 and $136.22 \mathrm{~mm}(92.47 \%)$ in the downstream region during 1992-2016 in the KRB. The variation caused by climate variability is $98.64 \mathrm{~mm}$ (87.96\%) in the upstream region during 1987-2016 and $-11.09 \mathrm{~mm}(7.53 \%)$ in the down- 
stream region between 1992 and 2016. The analysis of each six-year period, which was separated for the post impacted period, revealed that the most significant influence of climate change in the upstream $(285.60 \mathrm{~mm}$, i.e., $86.58 \%)$ and downstream areas $(82.87 \mathrm{~mm}$, i.e., 49.66\%) occurred during 2002-2006 and during 1992-1996, respectively. The most significant effect of human disturbances was observed from 2007 to 2011 in the upstream region at $217.70 \mathrm{~mm}(59.55 \%)$, while in the downstream region of the KRB, the most significant impact of human activities was $120.42 \mathrm{~mm}(84.11 \%)$ between 1997 and 2001. Our study revealed that in the runoff changes, the impact of the anthropogenic intervention was a dominant factor in the downstream region, and the impacts of climate change were the dominant factor in the upstream region of the KRB. This paper has shown that in the mountainous upstream part of the KRB, there is less exposure to human activities. Furthermore, the impact of climate change identified in this study and the analysis demonstrated that during the 66-year period, the trend of air temperature has continuously increased in the KRB. This phenomenon might cause rapid snowmelt in the KRB, which influenced the water cycle and hydrological process in the Kofarnihon River. The effect of climate variability on runoff variations between 1987 and 2016 was computed to be $87.96 \%$ in the upstream and $7.53 \%$ in the downstream regions of the Kofarnihon River Basin in Central Asia (Table 6).

Table 6. Climate variability and human activity contributions to runoff changes in the upstream and downstream areas of the Kofarnihon River Basin in Central Asia.

\begin{tabular}{|c|c|c|c|c|c|c|c|c|c|c|c|c|}
\hline \multirow{2}{*}{ Regions } & \multirow{2}{*}{\multicolumn{2}{|c|}{ Period }} & \multirow{2}{*}{$\begin{array}{c}R \\
(\mathrm{~mm})\end{array}$} & \multirow{2}{*}{$\begin{array}{c}P \\
(\mathrm{~mm})\end{array}$} & \multirow{2}{*}{$\begin{array}{c}\text { PET } \\
(\mathrm{mm})\end{array}$} & \multirow{2}{*}{$\frac{\Delta R}{(\mathrm{~mm})}$} & \multirow{2}{*}{$\frac{\Delta P}{(\mathrm{~mm})}$} & \multirow{2}{*}{$\begin{array}{l}\triangle P E T \\
(\mathrm{~mm})\end{array}$} & \multicolumn{2}{|c|}{$\Delta R_{\text {climate }}$} & \multicolumn{2}{|c|}{$\Delta R_{\text {human }}$} \\
\hline & & & & & & & & & $\mathrm{mm}$ & $\%$ & $\mathrm{~mm}$ & $\%$ \\
\hline \multirow{8}{*}{$\begin{array}{l}\text { Upstream } \\
\text { Basin }\end{array}$} & $\begin{array}{l}\text { Basline } \\
\text { Meaure }\end{array}$ & 1950-1986 & 972.23 & 374.21 & 1041.77 & & & & & & & \\
\hline & & 1987-1991 & 980.13 & 379.50 & 1041.64 & 7.90 & 5.29 & -0.12 & 35.42 & 56.28 & -27.52 & 43.72 \\
\hline & & 1992-1996 & 1162.83 & 384.72 & 1020.67 & 190.60 & 10.51 & -21.10 & 119.12 & 62.50 & 71.48 & 37.50 \\
\hline & & 1997-2001 & 947.46 & 370.37 & 1052.83 & -24.77 & -3.84 & 11.06 & -41.36 & 71.37 & 16.59 & 28.63 \\
\hline & & 2002-2006 & 1213.55 & 414.51 & 1049.99 & 241.33 & 40.31 & 8.22 & 285.60 & 86.58 & -44.28 & 13.42 \\
\hline & & 2007-2011 & 1042.03 & 360.05 & 1067.76 & 69.80 & -14.16 & 25.99 & -147.89 & 40.45 & 217.70 & 59.55 \\
\hline & & 2012-2016 & 998.18 & 393.79 & 1070.81 & 25.96 & 19.58 & 29.04 & 85.17 & 58.99 & -59.22 & 41.01 \\
\hline & & 1987-2016 & 1057.36 & 390.35 & 1050.47 & 85.14 & 16.14 & 8.70 & 98.64 & 87.96 & -13.51 & 12.04 \\
\hline \multirow{7}{*}{ Downstream Basin } & $\begin{array}{l}\text { Baseline } \\
\text { Meaure }\end{array}$ & 1950-1991 & 536.47 & 719.49 & 1205.01 & & & & & & & \\
\hline & & 1992-1996 & 703.37 & 749.30 & 1180.18 & 166.89 & 29.81 & -29.63 & 82.87 & 49.66 & 84.02 & 50.34 \\
\hline & & 1997-2001 & 634.16 & 712.93 & 1218.09 & 97.68 & -6.57 & 8.28 & -22.74 & 15.89 & 120.42 & 84.11 \\
\hline & & 2002-2006 & 709.35 & 761.57 & 1226.17 & 172.87 & 42.08 & 16.36 & 74.16 & 42.90 & 98.71 & 57.10 \\
\hline & & 2007-2011 & 622.96 & 688.45 & 1236.89 & 86.49 & -31.04 & 27.08 & -88.29 & 33.56 & 174.77 & 66.44 \\
\hline & & 2012-2016 & 638.17 & 680.99 & 1227.98 & 101.70 & -38.51 & 18.17 & -101.52 & 33.31 & 203.22 & 66.69 \\
\hline & & 1992-2016 & 661.60 & 718.65 & 1217.86 & 46.69 & -0.32 & 8.05 & -11.09 & 7.53 & 136.22 & 92.47 \\
\hline
\end{tabular}

\subsection{Land Use Changes over Kofarnihon River Basin}

Based on the geological developments, the Kofarnihon River Basin is associated with Central (Southern Tien Shan and Gissaro-Alai) and South-Western Tajikistan. The geological structure of the latter part essentially comprises Middle and Upper Paleozoic and, to a limited degree, Precambrian, Lower Paleozoic, Mesozoic, and Cenozoic deposits. The paper used the Harmonized World Soil Database (HWSD) version 1.2 with a scale of 1:5,000,000 to identify the soil type for the Kofarnihon River Basin [83]. On the website of the Food and Agriculture Organization of the United Nations, the HWSD is freely available. The most notable soil categories were cambisols $(48.69 \%)$, leptosols $(26.60 \%)$, calcisols (9.79\%), anthrosols (8.37\%), shifting dunes (3.53\%), and arenosols (3.02\%) [83].

As for anthropogenic intervention, construction land and agricultural irrigation are the respective factors that can confirm the expansion of human influences on water resources in the KRB. The construction land increased heavily and forest land increased insignificantly while agricultural land tended to decline. This implies that some areas of agricultural land were transformed into residential land. 
In the KRB, compared with 1990, the area of forest land, grass land, water body, and construction land increased by $0.13 \%, 1.08 \%, 17.57 \%$, and $175.69 \%$ in 2015 , respectively (Table 7). At the same time, the area of agricultural land and bare land decreased by $19.63 \%$ and $4.07 \%$, respectively. The dramatic changes showed that the population is growing and demand for construction land is also increasing. This causes high water demand in the KRB. As such, water managers are mandated to implement improved water use efficiency. Figure 10 demonstrates the land use type in the KRB based on the data, which were derived from the Institute of Ecology and Geography Chinese Academy of Sciences.

Table 7. Transformation of land use in the Kofarnihon River Basin in Central Asia in 1990, 2000, 2010, and 2015.

\begin{tabular}{cccccc}
\hline \multicolumn{2}{c}{ Land Use Type } & $\mathbf{1 9 9 0}$ & $\mathbf{2 0 0 0}$ & $\mathbf{2 0 1 0}$ & $\mathbf{2 0 1 5}$ \\
\hline \multirow{2}{*}{ Agricultural land } & Area $\left(\mathrm{km}^{2}\right)$ & 1900.11 & 1612.70 & 1572.78 & 1527.16 \\
& Rate $(\%)$ & & -15.12 & -17.23 & -19.63 \\
\multirow{2}{*}{ Forest land } & Area $\left(\mathrm{km}^{2}\right)$ & 423.70 & 421.99 & 424.27 & 424.27 \\
& Rate $(\%)$ & & -0.40 & 0.13 & 0.13 \\
\multirow{2}{*}{ Grass land } & Area $\left(\mathrm{km}^{2}\right)$ & 5733.41 & 5925.02 & 5798.42 & 5795.57 \\
& Rate $(\%)$ & & 3.34 & 1.13 & 1.08 \\
Construction land & Area $\left(\mathrm{km}^{2}\right)$ & 248.63 & 422.56 & 638.12 & 685.45 \\
& Rate $(\%)$ & & 69.69 & 156.65 & 175.69 \\
\multirow{2}{*}{ Water } & Area $\left(\mathrm{km}^{2}\right)$ & 32.50 & 33.65 & 38.21 & 38.21 \\
& Rate $(\%)$ & & 3.54 & 17.57 & 17.57 \\
\multirow{2}{*}{ Bare land } & Area $\left(\mathrm{km}^{2}\right)$ & 3251.63 & 3174.08 & 3118.19 & 3119.33 \\
& Rate $(\%)$ & & -2.38 & -4.10 & -4.07 \\
\hline
\end{tabular}
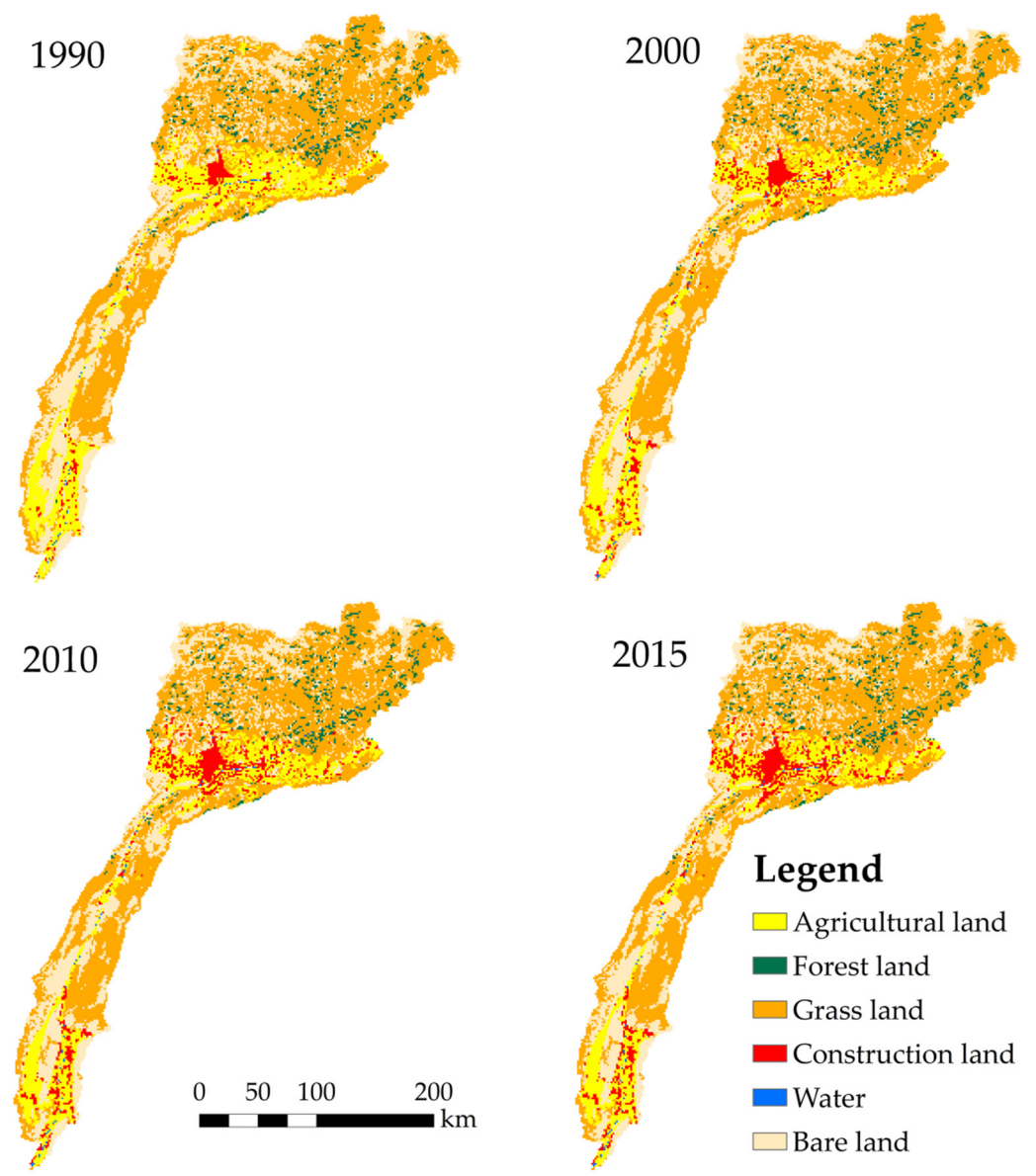

Figure 10. Land use category of the year 1990, 2000, 2010, and 2015 in Kofarnihon River Basin, Central Asia. 


\section{Discussion}

In Central Asia's mountainous region, a significant part of precipitation leads to the accumulation of snow during the winter and spring seasons. The river flow increases rapidly with the onset of snowmelt in March and April. In the Kofarnihon River Basin, the maximum amount of precipitation falls during winter and spring, which leads to a clear temporal separation of snow accumulation and the time of peak runoff. The Kofarnihon River is characterized by a seasonal cycle of river flow with a maximum flow in the summer season (Figure 2). Summer runoff of the upper catchments of Central Asian rivers is controlled by the melting of snow and glaciers, which account for up to $50 \%$ of the seasonal runoff to glacial catchments [84].

The Kofarnihon River is one of the major water tributaries in the Amu Darya River Basin. Its elevation ranges from 304 to $4830 \mathrm{~m}$ above sea level; it is the most vulnerable territory in Central Asia to hydroclimatic changes [85]. This river accounts for more than 9\% of its whole runoff [56]. The Amu Darya River is the second major inflow of the Aral Sea in Central Asia. It is characterized by the arid and semi-arid weather condition with limited water resources due to the increase in water demand as a result of demographic expansion and a larger change in water resources arising from the climate variation and severe anthropogenic disturbances. The terrestrial exploitation and residential land have strongly impacted the provision of water and water demand patterns in this region [86]. The Kofarnihon River with its tributaries serves as a water source for agriculture, municipal uses, and hydropower production in Central Asian countries. Previous studies have shown that both tropical and western circulation regimes simultaneously affect the climate of Central Asia, especially during the wet winter and spring seasons. Moreover, previous studies showed that hydroclimatic conditions over Central Asia are strongly influenced by the location and strength of the western jet stream $[87,88]$.

The climate of the KRB is continental under the impact of the westerlies direct of highly seasonal variations of precipitation and temperature. These variabilities are indicated to be because of the mountainous terrain of the catchment, which has a local contrast that is too strong and the most assailable area in Central Asia to hydro-climatic variability [67]. The south-western parts of the basin in summer are strongly influenced by the dry heat from the Afghanistan, Uzbekistan, and Turkmenistan deserts.

The application of the trend test to analyze the impact of climate change on runoff is a common practice implemented by many researchers [89-91]. In this study, the result of the modified MK test indicated that the trend of annual temperature and annual potential evapotranspiration significantly increased, while precipitation showed an insignificant decreasing trend in the upstream and downstream regions of the KRB. These findings are in line with the previous studies, which were carried out in Central Asia as well as with recent IPCC reports $[17,92,93]$. Our result of the trend analysis showed that annual runoff significantly increased in upstream and downstream areas of the KRB. In our previous study, we predicted a significant upward trend in the high flow of the Vakhsh River [32], which is adjacent to the Kofarnikhon River in Tajikistan. The upward trend in river runoff can be explained by the rapid melting of snow and ice caused by the constant rise in air temperature. Another phenomenon is that as the air temperature rises, the amount of snowfall will decrease while the amount of precipitation will increase [94]. In Tajikistan, glaciers and snow represent important water resources [95]. Glaciers and seasonal snow cover are the main sources of the formation of water resources in the Kofarnihon River [93]. Increasing snowmelt may be caused by the continuously increasing trend of air temperatures in the region, which will influence the water cycle and flow regime in the Kofarnihon River. Previous studies showed that temperature, precipitation, and potential evapotranspiration affect land-use transformation and could lead to larger variations in runoff [80].

In our study, the combination of the Pettitt test and double cumulative curve method demonstrated the change point in 1991 downstream of the Kofarnihon River Basin in Central Asia. Our findings are in agreement with the studies of Bissenbayeva et al. [31] 
in the Arys River Basin in Uzbekistan in Central Asia, where the Pettit test was also used together with the DCC method. In the upstream region of the catchment, the change point occurred in 1986, which is in agreement with the results of the Ma et al. [20] and Xue et al. [6] in the Shiyang and Tarim River Basins in Central Asia. Quantifying individual influences is difficult because most of the flow changes are associated with changes in both climate and anthropogenic intervention. In our study, the result of the climate elasticity method showed that the changes in runoff induced by anthropogenic intervention and climate change is $12.04 \%$ and $87.96 \%$ in the upstream region during the 1987-2016 and $92.47 \%$ and $7.53 \%$ in the downstream region during the 1992-2016 compared to the period of 1950-1986 and 1950-1991. It shows that in both upstream and downstream areas, the impact of anthropogenic intervention is a dominant factor contributing to runoff changes. Our findings are in line with the results of previous studies in the region of Central Asia including Arys and Keles River Basins in Uzbekistan, the Buqtyrma River Basin in Kazakhstan, and the Aksu River Basin in Xinjiang in Central Asia [6,30,31]. It should be noted that the climate elasticity method was also used in these basins. Don et al. [96] studied the influences of climate variation and anthropogenic intervention between 1975 and 2015 in the Nenjiang River Basin. Their results showed that in the mountain area, the anthropogenic activities were less, and in the downstream area, the effect of anthropogenic activities was greater. Since the 1990s, human disturbances have had a rising effect on runoff changes due to the fast population growth, economic development, the building of water conservancy plan facilities, and growth in the planting zone for agricultural products. Zhou et al. [19] used the climate elasticity method in the Dongjiang River Basin (DRB) and reported that the influences of anthropogenic interventions on runoff variability in the lower parts was greater than in the upper parts in the catchment. The effect caused by anthropogenic activities on runoff variability was $37 \%$ in the upstream and $84 \%$ in the downstream of the DRB. Sharma et al. described that the human disturbances played a major role in declining runoff trends in the Tapi Basin in the West Central India, contributing a roughly 68-99\% decline in the total runoff compared to rainfall variability, which contributed a roughly 1-32\% decrease in total runoff [34]. Chang et al. [18] confirmed that in the Weihe River Basin in China, anthropogenic disturbances have a stronger influence on catchment runoff than other factors, which would be caused by the climate variability. However, Zhao et al. reported that the climate variability has a stronger impact on the runoff decrease in the Beiluo and Yan watersheds in the Yellow River Basin, whereas anthropogenic disturbances had a larger contribution in the runoff variations in other water arteries, particularly in the northern watersheds [3]. Ma et al. investigated that in the Shiyang Basin, climate change contributed about $64 \%$ of the decrease in mean annual flow, mainly due to the decreased precipitation, and flow is more prone to fluctuations in precipitation compared to potential evapotranspiration [20]. Li et al. confirmed that the climate variability accounted for $69-71 \%$ of annual runoff reduction and anthropogenic intervention $29-31 \%$ in the upper catchment of the Red River Basin [21]. In the Songhua River Basin, the anthropogenic activities had a stronger influence (62-82\%) on the overall runoff changes from 1975 to 2009 [35]. Zeng et al. confirmed that in the annual runoff changes, the factors impacted by climate are greater than factors impacted by anthropogenic activities in the Zhang River Basin [97]. However, in this study, the influence of anthropogenic intervention was the dominant factor compared to climate variability on runoff.

In the early 1990s, after the collapse of the Soviet Union, due to the restructuring of state and collective farms into small farms, the area of irrigated land also decreased and water intake for irrigation decreased [98]. After the 1990s, in these areas, the amount of irrigated land increased dramatically, where people used the land to grow wheat, rice, and vegetables. After the 1990s, the population in the basin increased, and the middle and lower reaches of the basin are one of the most densely populated regions of Tajikistan. With the growth of population after the 1990s, some of the irrigated land transferred into human settlements. To this day, the population of the catchment is growing. Population growth has a major impact on water resources. Population growth is approximately $2.5 \%$, which 
needs to be ensured in terms of water supply, food production, electricity, and housing. In 1991, water resources in Tajikistan amounted to $11,963 \mathrm{~m}^{3}$ per capita and the area of irrigated land per capita was $0.13 \mathrm{ha}$. In 2015, these units per capita changed to $7711 \mathrm{~m}^{3}$ and 0.09 ha, respectively [99]. Moreover, the growing demand for irrigation water in agriculture and human settlements will therefore lead to an increase in water consumption.

It should be noted that there are uncertainties in the outcomes given the assumption that runoff changes caused by precipitation-runoff variations were due to climate change and human activities, which are independent of one another. The simulation preciseness of hydro-climatic including precipitation and potential evapotranspiration may be altered because of the limited number and distribution of the climate stations. Hence, climate change may impact anthropogenic activities including land use, increasing urbanization, and a growing population may induce variations in water resources. Despite negligible limitations and uncertainties, this analysis led to a robust quantitative investigation of the effects of climate change and anthropogenic intervention on the runoff variations in the KRB. Further investigations could focus on the reduction of uncertainties and combining the climate measured data along with global climate model (GCM) data linked with a hydrological model to project the effects of climate variability and anthropogenic disturbances on water resources in the Kofarnihon River Basin in Central Asia.

\section{Conclusions}

The purpose of the current work was to quantitatively identify the contributions of climate change and anthropogenic activities on runoff variation in the upstream and downstream regions of the Kofarnihon River Basin in Central Asia. Following the long-term data, the trend and magnitude change of potential evapotranspiration, temperature, precipitation, and runoff were identified by using original and modified Mann-Kendall tests and Sen's slope estimator. The change point of the hydro-climatic series was determined by applying Pettitt's test and double cumulative curve method during the 1950-2016 time period. The climate elasticity method was used to evaluate the contribution to runoff variation caused by climate change and human activities. The study time series were divided into the prior impacted period 1950-1986 and 1950-1991 and the post impacted period 1987-2016 and 1992-2016 for the upstream and downstream regions of the KRB. The main findings of this paper can be concluded as follows:

(1) The result of trend analysis showed an increasing trend in annual temperature at a rate of $0.0108^{\circ} \mathrm{C} /$ year in the upstream region and a rate of $0.023^{\circ} \mathrm{C} /$ year in the downstream region during the 1950-2016. The trend of annual potential evapotranspiration increased at a rate of $0.3899 \mathrm{~mm} /$ year and $0.4142 \mathrm{~mm} /$ year in the upstream and downstream. The annual runoff showed an increasing trend of about $2.4574 \mathrm{~mm} /$ year and 1.3361 in the upstream and downstream of the catchment. We revealed a statistically significant increasing trend in the annual runoff, potential evapotranspiration, and temperature over 1950-2016 in the KRB. Annul precipitation demonstrated slightly a decreasing trend in both the upstream and downstream at a rate of $-0.2134 \mathrm{~mm} /$ year and $-0.0124 \mathrm{~mm} /$ year; however, the trend decreased (not statistically significant). The change point for the annual mean temperature occurred around 1996 and 1976, for precipitation in 1969, and potential evapotranspiration in 1998 over 1950-2016 in the upstream and downstream areas. The runoff change point in the upstream region was detected in 1986 by Pettitt's test and in 2004 by the double cumulative curve method and in the downstream region, both approaches showed the change point in 1991.

(2) The area of the construction land or residential land in 1990 was $248.63 \mathrm{~km}^{2}$ and increased to $685.45 \mathrm{~km}^{2}$ in 2015 . The area of agricultural land in 1990 was $1900.11 \mathrm{~km}^{2}$, which decreased to $1527.16 \mathrm{~km}^{2}$ in 2015 . These discrepancies show that land use in the middle and downstream areas changed from agriculture to residential due to the growing population in the Kofarnihon River Basin in Central Asia. 
(3) The result of the climate elasticity method showed that the effect of climate change on runoff variation in the post impacted period (1987-2016) is $98.64 \mathrm{~mm}(87.96 \%)$ in the upstream and $-11.09 \mathrm{~mm}(7.53 \%)$ in the downstream. In the post impacted period, the change in runoff caused by anthropogenic activities is -13.51 (12.04\%) in the upstream and $136.22 \mathrm{~mm}(92.47 \%)$ in the downstream. Our result showed that among all sub-periods, the most significant impact of climate change $285.60 \mathrm{~mm}$ (86.58\%) occurred between 2002 and 2006 in the upstream and $82.87 \mathrm{~mm}(49.66 \%)$ from 1992 to 1996 in the downstream areas. The most significant impact of human activities in the upstream region is $217.70 \mathrm{~mm}(59.55 \%)$ between 2007 and 2011, and in the downstream region is $120.42 \mathrm{~mm}(84.11 \%)$ between 1997 and 2001. In this study, the impact of anthropogenic activities was a dominant factor in the runoff changes in the downstream region, and in the upstream region, the dominant factor was climate change, while the upstream region was less exposed to human activities due to the mountainous area. Climate change influences on runoff variations in the upstream were greater than in the downstream of the catchment. The continuously increasing air temperature might have induced rapid snowmelt, which caused an increase in high and median runoff in the catchment.

The runoff is an essential part of the hydrological cycle, as the runoff variability can significantly influence human's safety, ecosystem well-being, and water resources. This study can provide suggestions for decision-makers and researchers to restrict human intervention to a reasonable range in the degraded agricultural land, which is being transferred to construction lands, and to create relevant adaptation measures for the mitigation of climate change impacts on the water resources and a reasonable allocation of water resources in the upstream and downstream regions of the Kofarnihon River Basin in Central Asia.

Author Contributions: All authors were involved in the intellectual elements of this paper. Conceptualization, N.G. and Y.C.; formal analysis and writing — original draft preparation, N.G.; writingreview and editing, A.G.; methodology, A.G. and M.R.; data curation and investigation, M.G. All authors have read and agreed to the published version of the manuscript.

Funding: The research is supported by the National Natural Science Foundation of China (U1903208, 42071046) and the Strategic Priority Research Program of the Chinese Academy of Sciences (No. XDA19030204).

Data Availability Statement: Not applicable.

Acknowledgments: Nekruz Gulahmadov would like to express his sincere gratitude to the Chinese Academy of Science (CAS) and the World Academy of Science for the Developing World (TWAS) Presidents Fellowship program for international Ph.D. students (Awardee of 2019 CAS-TWAS Presidents fellowship) for financial support of this study. The authors are thankful to the Ministry of Energy and Water Resources of the Republic of Tajikistan and the Agency of Hydrometeorology of the Committee for Environmental Protection under the Government of the Republic of Tajikistan for providing the data for this research.

Conflicts of Interest: The authors declare no conflict of interest.

\section{Appendix A. Software Package, "Modifiedmk"}

The modified MK test initiated by Hamed and Rao [100] was applied to estimate the trends of serial correlation data. Afterwards, Yue et al. [101] initiated a nonparametric modified MK trend method that is appropriate for autocorrelated data following the modified value in the difference of the test statistic. The correctness of this modified test in terms of its empirical significance was revealed to be superior to the original Mann-Kendall trend test due to the absence of any loss of power. The open-course library package named "modifiedmk" was developed in the R-language [102]. In this study, the nonparametric Mann-Kendall tests and all modified versions of the Mann-Kendall tests were calculated by using the "modifiedmk" package. The "modifiedmk" package is now freely accessible 
via the CRAN source and GitHub version control platform [103]. Fixed modification indication is determined as below, and from Equations (A1) and (A2), the $Z$ values are identified [101]:

$$
\begin{gathered}
V(S)=\operatorname{Var}(S) \times \frac{n}{n_{s}^{*}}=\frac{n(n-1)(2 n+5)}{18} \times \frac{n}{n_{s}^{*}} \\
\frac{n}{n_{s}^{*}}=1+\frac{2}{n(n-1)(n-2)} \times \sum_{i=1}^{n-1}(n-i)(n-i-2) \rho_{s}(i)
\end{gathered}
$$

where $n / n_{s}{ }^{*}$ indicates a modification due to autocorrelation in the data, " $n$ " is the actual value of measurement point, and $\rho_{s}$ (i) is the autocorrelation of the measurement ranks. The RStudio software, version 3.5.3, was used to compute all MK, MMK, and Pettitt's tests results of the current research.

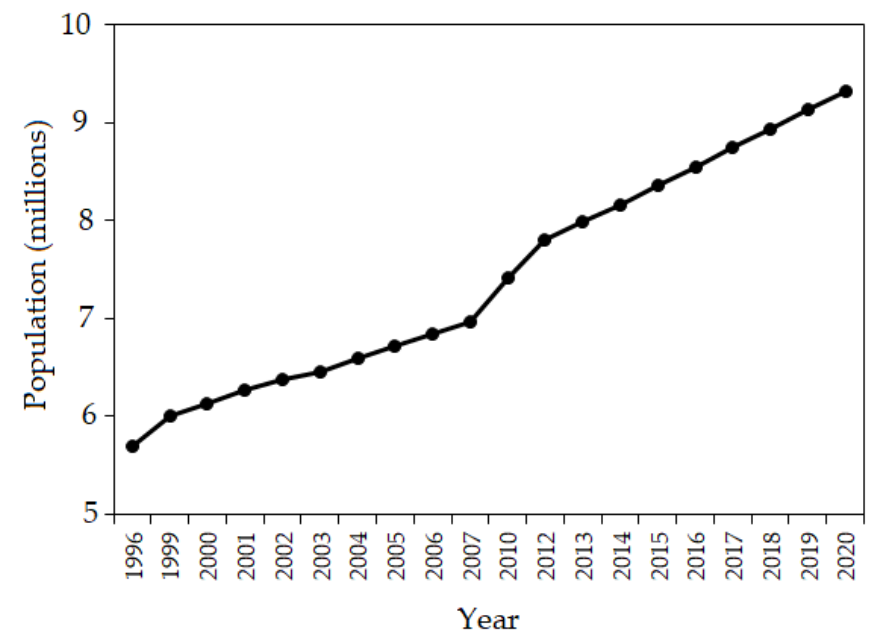

Figure A1. Population growth rates per annum by the intercensal period 1996-2020, Tajikistan, Central Asia.

\section{References}

1. Jiang, Z.; Li, W.; Xu, J.; Li, L. Extreme precipitation indices over China in CMIP5 models. Part I: Model evaluation. J. Clim. 2015, 28, 8603-8619. [CrossRef]

2. Piao, S.; Ciais, P.; Huang, Y.; Shen, Z.; Peng, S.; Li, J.; Zhou, L.; Liu, H.; Ma, Y.; Ding, Y. The impacts of climate change on water resources and agriculture in China. Nature 2010, 467, 43-51. [CrossRef] [PubMed]

3. Zhao, G.; Tian, P.; Mu, X.; Jiao, J.; Wang, F.; Gao, P. Quantifying the impact of climate variability and human activities on streamflow in the middle reaches of the Yellow River basin, China. J. Hydrol. 2014, 519, 387-398. [CrossRef]

4. Zhang, Y.; Guan, D.; Jin, C.; Wang, A.; Wu, J.; Yuan, F. Analysis of impacts of climate variability and human activity on streamflow for a river basin in northeast China. J. Hydrol. 2011, 410, 239-247. [CrossRef]

5. Milly, P.C.; Dunne, K.A.; Vecchia, A.V. Global pattern of trends in streamflow and water availability in a changing climate. Nature 2005, 438, 347-350. [CrossRef] [PubMed]

6. Xue, L.; Yang, F.; Yang, C.; Chen, X.; Zhang, L.; Chi, Y.; Yang, G. Identification of potential impacts of climate change and anthropogenic activities on streamflow alterations in the Tarim River Basin, China. Sci. Rep. 2017, 7, 1-12. [CrossRef]

7. Wada, Y.; Bierkens, M.F.; Roo, A.d.; Dirmeyer, P.A.; Famiglietti, J.S.; Hanasaki, N.; Konar, M.; Liu, J.; Müller Schmied, H.; Oki, T. Human-water interface in hydrological modelling: Current status and future directions. Hydrol. Earth Syst. Sci. 2017, 21, 4169-4193. [CrossRef]

8. Ranasinghe, R.; Wu, C.S.; Conallin, J.; Duong, T.M.; Anthony, E.J. Disentangling the relative impacts of climate change and human activities on fluvial sediment supply to the coast by the world's large rivers: Pearl River Basin, China. Sci. Rep. 2019, 9, 1-10.

9. Hijioka, Y.; Lin, E.; Pereira, C.; Corlett, R.; Cui, X.; Insarov, G.; Lasco, R.; Lindgren, E.; Surjan, A. Asia. In Climate Change 2014: Impacts, Adaptation, and Vulnerability. Part B: Regional Aspects. Contribution of Working Group II to the Fifth Assessment Report of the Intergovernmental Panel of Climate Change; Barros, V.R., Field, C.B., Dokken, D.J., Mastrandrea, M.D., Mach, K.J., Bilir, T.E., Chatterjee, M., Ebi, K.L., Estrada, Y.O., Genova, R.C., et al., Eds.; Cambridge University Press: Cambridge, UK; New York, NY, USA, 2014; pp. 1327-1370.

10. Punkari, M.; Droogers, P.; Immerzeel, W.; Korhonen, N.; Lutz, A.; Venäläinen, A. Climate change and sustainable water management in Central Asia. Asian Dev. Bank 2014, 5, 1-27. 
11. Tarboton, D. Rainfall-runoff processes. Utah State Univ. 2003, 1, 1-159.

12. Wang, D.; Yu, X.; Jia, G.; Wang, H. Sensitivity analysis of runoff to climate variability and land-use changes in the Haihe Basin mountainous area of north China. Agric. Ecosyst. Environ. 2019, 269, 193-203. [CrossRef]

13. Alizadeh, B.; Limon, R.A.; Seo, D.-J.; Lee, H.; Brown, J. Multiscale post-processor for ensemble streamflow prediction for short-to-long ranges. J. Hydrometeorol. 2019, 1, 1-125.

14. Dong, L.; Zhang, G.; Xu, Y. Effects of climate change and human activities on runoff in the Nenjiang River Basin, Northeast China. Hydrol. Earth Syst. Sci. Discuss. 2012, 9, 11521-11549.

15. Oki, T.; Kanae, S. Global hydrological cycles and world water resources. Science 2006, 313, 1068-1072. [CrossRef] [PubMed]

16. Prestele, R.; Arneth, A.; Bondeau, A.; de Noblet-Ducoudré, N.; Pugh, T.A.; Sitch, S.; Stehfest, E.; Verburg, P.H. Current challenges of implementing anthropogenic land-use and land-cover change in models contributing to climate change assessments. Earth Syst. Dyn. 2017. [CrossRef]

17. Pachauri, R.K.; Allen, M.R.; Barros, V.R.; Broome, J.; Cramer, W.; Christ, R.; Church, J.; Clarke, L.; Dahe, Q.; Dasgupta, P. Climate Change 2014: Synthesis Report. Contribution of Working Groups I, II and III to the Fifth Assessment Report of the Intergovernmental Panel on Climate Change; IPCC: Geneva, Switzerland, 2014.

18. Chang, J.; Wang, Y.; Istanbulluoglu, E.; Bai, T.; Huang, Q.; Yang, D.; Huang, S. Impact of climate change and human activities on runoff in the Weihe River Basin, China. Quat. Int. 2015, 380, 169-179. [CrossRef]

19. Zhou, Y.; Lai, C.; Wang, Z.; Chen, X.; Zeng, Z.; Chen, J.; Bai, X. Quantitative evaluation of the impact of climate change and human activity on runoff change in the Dongjiang River Basin, China. Water 2018, 10, 571. [CrossRef]

20. Ma, Z.; Kang, S.; Zhang, L.; Tong, L.; Su, X. Analysis of impacts of climate variability and human activity on streamflow for a river basin in arid region of northwest China. J. Hydrol. 2008, 352, 239-249. [CrossRef]

21. Li, Y.; He, D.; Li, X.; Zhang, Y.; Yang, L. Contributions of climate variability and human activities to runoff changes in the upper catchment of the Red River Basin, China. Water 2016, 8, 414. [CrossRef]

22. Li, Y.; Chang, J.; Wang, Y.; Jin, W.; Guo, A. Spatiotemporal impacts of climate, land cover change and direct human activities on runoff variations in the Wei River Basin, China. Water 2016, 8, 220. [CrossRef]

23. Guo, Q.; Yang, Y.; Xiong, X. Using hydrologic simulation to identify contributions of climate change and human activity to runoff changes in the Kuye river basin, China. Environ. Earth Sci. 2016, 75, 417. [CrossRef]

24. Zhao, C.; Liu, C.; Dai, X.; Liu, T.; Duan, Z.; Liu, L.; Mitrovic, S.M. Separation of the impacts of climate change and human activity on runoff variations. Hydrol. Sci. J. 2015, 60, 234-246. [CrossRef]

25. Wang, S.; Wang, Y.; Ran, L.; Su, T. Climatic and anthropogenic impacts on runoff changes in the Songhua River basin over the last 56 years (1955-2010), Northeastern China. Catena 2015, 127, 258-269. [CrossRef]

26. Yan, X.; Bao, Z.; Zhang, J.; Wang, G.; He, R.; Liu, C. Quantifying contributions of climate change and local human activities to runoff decline in the upper reaches of the Luanhe River basin. J. Hydro. Environ. Res. 2020, 28, 67-74. [CrossRef]

27. Li, B.; Yu, Z.; Liang, Z.; Song, K.; Li, H.; Wang, Y.; Zhang, W.; Acharya, K. Effects of climate variations and human activities on runoff in the Zoige alpine wetland in the eastern edge of the Tibetan Plateau. J. Hydrol. Eng. 2014, 19, 1026-1035. [CrossRef]

28. Bu, J.; Lu, C.; Niu, J.; Gao, Y. Attribution of runoff reduction in the Juma River basin to climate variation, direct human intervention, and land use change. Water 2018, 10, 1775. [CrossRef]

29. Lee, S.; Kim, S.U. Quantification of hydrological responses due to climate change and human activities over various time scales in South Korea. Water 2017, 9, 34. [CrossRef]

30. Rakhimova, M.; Liu, T.; Bissenbayeva, S.; Mukanov, Y.; Gafforov, K.S.; Bekpergenova, Z.; Gulakhmadov, A. Assessment of the impacts of climate change and human activities on runoff using climate elasticity method and General Circulation Model (GCM) in the Buqtyrma River Basin, Kazakhstan. Sustainability 2020, 12, 4968. [CrossRef]

31. Bissenbayeva, S.; Abuduwaili, J.; Shokparova, D.; Saparova, A. Variation in runoff of the Arys river and keles river watersheds (Kazakhstan), as influenced by climate variation and human activity. Sustainability 2019, 11, 4788. [CrossRef]

32. Gulakhmadov, A.; Chen, X.; Gulahmadov, N.; Liu, T.; Anjum, M.N.; Rizwan, M. Simulation of the potential impacts of projected climate change on streamflow in the Vakhsh river basin in central Asia under CMIP5 RCP scenarios. Water 2020, $12,1426$. [CrossRef]

33. Guo, L.-P.; Mu, X.-M.; Hu, J.-M.; Gao, P.; Zhang, Y.-F.; Liao, K.-T.; Bai, H.; Chen, X.-L.; Song, Y.-J.; Jin, N. Assessing impacts of climate change and human activities on streamflow and sediment discharge in the Ganjiang River basin (1964-2013). Water 2019, 11, 1679. [CrossRef]

34. Sharma, P.J.; Patel, P.; Jothiprakash, V. Impact of rainfall variability and anthropogenic activities on streamflow changes and water stress conditions across Tapi Basin in India. Sci. Total Environ. 2019, 687, 885-897. [CrossRef] [PubMed]

35. Li, F.; Zhang, G.; Xu, Y.J. Separating the impacts of climate variation and human activities on runoff in the Songhua River Basin, Northeast China. Water 2014, 6, 3320-3338. [CrossRef]

36. Chen, Z.; Chen, Y.; Li, B. Quantifying the effects of climate variability and human activities on runoff for Kaidu River Basin in arid region of northwest China. Theor. Appl. Climatol. 2013, 111, 537-545. [CrossRef]

37. Guo, Y.; Li, Z.; Amo-Boateng, M.; Deng, P.; Huang, P. Quantitative assessment of the impact of climate variability and human activities on runoff changes for the upper reaches of Weihe River. Stoch. Environ. Res. Risk Assess. 2014, 28, 333-346. [CrossRef]

38. Gao, P.; Mu, X.-M.; Wang, F.; Li, R. Changes in streamflow and sediment discharge and the response to human activities in the middle reaches of the Yellow River. Hydrol. Earth Syst. Sci. 2011, 15, 1. [CrossRef] 
39. Donohue, R.J.; Roderick, M.L.; McVicar, T.R. Assessing the differences in sensitivities of runoff to changes in climatic conditions across a large basin. J. Hydrol. 2011, 406, 234-244. [CrossRef]

40. Bao, Z.; Zhang, J.; Wang, G.; Fu, G.; He, R.; Yan, X.; Jin, J.; Liu, Y.; Zhang, A. Attribution for decreasing streamflow of the Haihe River basin, northern China: Climate variability or human activities? J. Hydrol. 2012, 460, 117-129. [CrossRef]

41. Ahn, K.-H.; Merwade, V. Quantifying the relative impact of climate and human activities on streamflow. J. Hydrol. 2014, 515, 257-266. [CrossRef]

42. Mango, L.M.; Melesse, A.M.; McClain, M.E.; Gann, D.; Setegen, S. Land use and climate change impacts on the hydrology of the upper Mara River Basin, Kenya: Results of a modeling study to support better resource management. Hydrol. Earth Syst. Sci. 2010, 15, 2245-2258. [CrossRef]

43. Bourgault, M.; Larocque, M.; Roy, M. Simulation of aquifer-peatland-river interactions under climate change. Hydrol. Res. 2014, 45, 425-440. [CrossRef]

44. Xu, X.; Yang, H.; Yang, D.; Ma, H. Assessing the impacts of climate variability and human activities on annual runoff in the Luan River basin, China. Hydrol. Res. 2013, 44, 940-952. [CrossRef]

45. Schilling, K.E.; Chan, K.-S.; Liu, H.; Zhang, Y.-K. Quantifying the effect of land use land cover change on increasing discharge in the Upper Mississippi River. J. Hydrol. 2010, 387, 343-345. [CrossRef]

46. Dvory, N.Z.; Ronen, A.; Livshitz, Y.; Adar, E.; Kuznetsov, M.; Yakirevich, A. Quantification of groundwater recharge from an ephemeral stream into a mountainous karst aquifer. Water 2018, 10, 79. [CrossRef]

47. Teng, F.; Huang, W.; Ginis, I. Hydrological modeling of storm runoff and snowmelt in Taunton River Basin by applications of HEC-HMS and PRMS models. Nat. Hazards 2018, 91, 179-199. [CrossRef]

48. Chiew, F.H.; Peel, M.C.; McMahon, T.A.; Siriwardena, L. Precipitation elasticity of streamflow in catchments across the world. IAHS Publ. 2006, 308, 256.

49. Fu, G.; Charles, S.P.; Chiew, F.H.S. A two-parameter climate elasticity of streamflow index to assess climate change effects on annual streamflow. Water Resour. Res. 2007, 43. [CrossRef]

50. Arora, V.K. The use of the aridity index to assess climate change effect on annual runoff. J. Hydrol. 2002, 265, 164-177. [CrossRef]

51. Wang, W.; Zou, S.; Shao, Q.; Xing, W.; Chen, X.; Jiao, X.; Luo, Y.; Yong, B.; Yu, Z. The analytical derivation of multiple elasticities of runoff to climate change and catchment characteristics alteration. J. Hydrol. 2016, 541, 1042-1056. [CrossRef]

52. Zhang, L.; Dawes, W.; Walker, G. Response of mean annual evapotranspiration to vegetation changes at catchment scale. Water Resour. Res. 2001, 37, 701-708. [CrossRef]

53. Zhang, Y.; Su, F.; Hao, Z.; Xu, C.; Yu, Z.; Wang, L.; Tong, K. Impact of projected climate change on the hydrology in the headwaters of the Yellow River basin. Hydrol. Process. 2015, 29, 4379-4397. [CrossRef]

54. Williams, M.; Konovalov, V. Central Asia Temperature and Precipitation Data, 1879-2003; Version 1; National Snow and Ice Data Center: Boulder, CO, USA, 2008. [CrossRef]

55. Aalto, J.; Kämäräinen, M.; Shodmonov, M.; Rajabov, N.; Venäläinen, A. Features of Tajikistan's past and future climate. Int. J. Climatol. 2017, 37, 4949-4961. [CrossRef]

56. Dukhovniy, V.A.Z.; Ziganshina, D.R.; Sorokin, A.G.; Sorokin, D.A.; Stulina, G.V.; Solodky, G.F.; Muminov, S.H.; Makhramov, M.Y.T.; Tilyavova, G.K.; Nazariy, A.M.; et al. The Future of the Amu Darya River Basin in the Condition of Changing Climate. Interstate Commission for Water Coordination in Central Asia. Available online: www.cawater-infor.net/project/peer-amudarya/ (accessed on 18 May 2018).

57. Shultz, V.L. РекиСреднейАзии. ЧастиI иII; Gidrometeoizdat: Saint Petersburg, Russia, 1965; Available online: http://www. cawater-info.net/library/rus/hist/shultz2/pages/002.htm (accessed on 21 December 2019). (In Russian)

58. Catalog of glaciers of the USSR. СредняяАзия. Выпуск3. Амударья. Часть05. БассейнрекиКачирнигана; Gidrometeoizdat: Saint Petersburg, Russia, 1980; Available online: https:/ / www.twirpx.com/file/1519456/ (accessed on 10 January 2020). (In Russian)

59. Zhang, Y.; You, Q.; Chen, C.; Ge, J. Impacts of climate change on streamflows under RCP scenarios: A case study in Xin River Basin, China. Atmos. Res. 2016, 178, 521-534. [CrossRef]

60. Allen, R.G.; Pereira, L.S.; Raes, D.; Smith, M. Crop Evapotranspiration-Guidelines for Computing Crop Water Requirements-FAO Irrigation and Drainage Paper 56; FAO: Rome, Italy, 1998; Volume 300, p. D05109.

61. Hargreaves, G.H.; Samani, Z.A. Reference crop evapotranspiration from temperature. Appl. Eng. Agric. 1985, 1, 96-99. [CrossRef]

62. Makkink, G.F. Testing the Penman formula by means of lysimeters. J. Inst. Water Eng. 1957, 11, $277-288$.

63. Priestley, C.H.B.; TAYLOR, R.J. On the assessment of surface heat flux and evaporation using large-scale parameters. Mon. Weather Rev. 1972, 100, 81-92. [CrossRef]

64. Jensen, M.E.; Haise, H.R. Estimating evapotranspiration from solar radiation. J. Irrig. Drain. Div. 1963, 89, 15-41. [CrossRef]

65. Guo, H.; Bao, A.; Liu, T.; Ndayisaba, F.; Jiang, L.; Kurban, A.; De Maeyer, P. Spatial and temporal characteristics of droughts in Central Asia during 1966-2015. Sci. Total Environ. 2018, 624, 1523-1538. [CrossRef]

66. Gupta, H.V.; Kling, H.; Yilmaz, K.K.; Martinez, G.F. Decomposition of the mean squared error and NSE performance criteria: Implications for improving hydrological modelling. J. Hydrol. 2009, 377, 80-91. [CrossRef]

67. Moriasi, D.N.; Arnold, J.G.; Van Liew, M.W.; Bingner, R.L.; Harmel, R.D.; Veith, T.L. Model evaluation guidelines for systematic quantification of accuracy in watershed simulations. Trans. ASABE 2007, 50, 885-900. [CrossRef]

68. Ren, P.; Li, J.; Feng, P.; Guo, Y.; Ma, Q. Evaluation of multiple satellite precipitation products and their use in hydrological modelling over the Luanhe River basin, China. Water 2018, 10, 677. [CrossRef] 
69. KGE Package 'hydroGOF'. 2020. Available online: https://cran.r-project.org/web/packages/hydroGOF/hydroGOF.pdf (accessed on 9 September 2020).

70. Hamed, K.H. Trend detection in hydrologic data: The Mann-Kendall trend test under the scaling hypothesis. J. Hydrol. 2008, 349, 350-363. [CrossRef]

71. Mavromatis, T.; Stathis, D. Response of the water balance in Greece to temperature and precipitation trends. Theor. Appl. Climatol. 2011, 104, 13-24. [CrossRef]

72. Yue, S.; Wang, C.Y. Applicability of prewhitening to eliminate the influence of serial correlation on the Mann-Kendall test. Water Resour. Res. 2002, 38, 4-1-4-7. [CrossRef]

73. Şen, Z. Probabilistic formulation of spatio-temporal drought pattern. Theor. Appl. Climatol. 1998, 61, 197-206. [CrossRef]

74. Pettitt, A. A non-parametric approach to the change-point problem. J. R. Stat. Soc. Ser. C 1979, 28, 126-135. [CrossRef]

75. Searcy, J.K.; Hardison, C.H. Double-Mass Curves; US Government Printing Offce: Washington, DC, USA, 1960.

76. Gao, P.; Li, P.; Zhao, B.; Xu, R.; Zhao, G.; Sun, W.; Mu, X. Use of double mass curves in hydrologic benefit evaluations. Hydrol. Process. 2017, 31, 4639-4646. [CrossRef]

77. Budyko, M.I.; Miller, D.H.; Miller, D.H. Climate and Life; Academic Press: New York, NY, USA, 1974; Volume 508.

78. Zhang, L.; Hickel, K.; Dawes, W.R.; Chiew, F.H.S.; Western, A.W.; Briggs, P.R. A rational function approach for estimating mean annual evapotranspiration. Water Resour. Res. 2004, 40. [CrossRef]

79. Gulakhmadov, A.; Chen, X.; Gulahmadov, N.; Liu, T.; Davlyatov, R.; Sharofiddinov, S.; Gulakhmadov, M. Long-Term hydroclimatic trends in the mountainous kofarnihon river basin in central asia. Water 2020, 12, 2140. [CrossRef]

80. Wang, W.; Shao, Q.; Yang, T.; Peng, S.; Xing, W.; Sun, F.; Luo, Y. Quantitative assessment of the impact of climate variability and human activities on runoff changes: A case study in four catchments of the Haihe River basin, China. Hydrol. Process. 2013, 27, 1158-1174. [CrossRef]

81. Peng, S.; Liu, W.; Wang, W.; Shao, Q.; Jiao, X.; Yu, Z.; Xing, W.; Xu, J.; Zhang, Z.; Luo, Y. Estimating the effects of climatic variability and human activities on streamflow in the Hutuo River Basin, China. J. Hydrol. Eng. 2013, 18, 422-430. [CrossRef]

82. Wu, J.; Wang, Z.; Dong, Z.; Tang, Q.; Lv, X.; Dong, G. Analysis of natural streamflow variation and its influential factors on the Yellow River from 1957 to 2010. Water 2018, 10, 1155. [CrossRef]

83. Food and Agriculture Organization. International Institute for Applied Systems Analysis; International Soil Reference and Information Centre. JRC: Harmonized World Soil Database (Version 1.2); FAO: Rome, Italy; IIASA: Laxenburg, Austria, 2012.

84. Hill, A.F.; Minbaeva, C.K.; Wilson, A.M.; Satylkanov, R. Hydrologic controls and water vulnerabilities in the Naryn River basin, Kyrgyzstan: A socio-hydro case study of water stressors in Central Asia. Water 2017, 9, 325. [CrossRef]

85. World Bank. Key Issues for Consideration on the Proposed Rogun Hydropower Project. Available online: http://www. worldbank.org/content/dam/Worldbank/Event/ECA/central-asia/ (accessed on 10 September 2019).

86. Yin, G.; Hu, Z.; Chen, X.; Tiyip, T. Vegetation dynamics and its response to climate change in Central Asia. J. Arid Land 2016, 8, 375-388. [CrossRef]

87. Schiemann, R.; Lüthi, D.; Vidale, P.L.; Schär, C. The precipitation climate of central Asia-Intercomparison of observational and numerical data sources in a remote semiarid region. Int. J. Climatol. A J. R. Meteorol. Soc. 2008, 28, 295-314. [CrossRef]

88. Schiemann, R.; Lüthi, D.; Schär, C. Seasonality and interannual variability of the westerly jet in the Tibetan Plateau region. J. Clim. 2009, 22, 2940-2957. [CrossRef]

89. Tan, M.L.; Samat, N.; Chan, N.W.; Lee, A.J.; Li, C. Analysis of precipitation and temperature extremes over the Muda River Basin, Malaysia. Water 2019, 11, 283. [CrossRef]

90. Jha, M.K.; Singh, A.K. Trend analysis of extreme runoff events in major river basins of Peninsular Malaysia. Int. J. Water 2013, 7, 142-158. [CrossRef]

91. Yagbasan, O.; Demir, V.; Yazicigil, H. Trend Analyses of Meteorological Variables and Lake Levels for Two Shallow Lakes in Central Turkey. Water 2020, 12, 414. [CrossRef]

92. Hu, Z.; Zhou, Q.; Chen, X.; Qian, C.; Wang, S.; Li, J. Variations and changes of annual precipitation in Central Asia over the last century. Int. J. Climatol. 2017, 37, 157-170. [CrossRef]

93. Li, Z.; Chen, Y.; Fang, G.; Li, Y. Multivariate assessment and attribution of droughts in Central Asia. Sci. Rep. 2017, 7, 1-12. [CrossRef]

94. Omani, N.; Srinivasan, R.; Karthikeyan, R.; Reddy, V.; Smith, P.K. Impacts of climate change on the glacier melt runoff from five river basins. Trans. ASABE 2016, 59, 829-848.

95. Hock, R. Glacier melt: A review of processes and their modelling. Prog. Phys. Geogr. 2005, 29, 362-391. [CrossRef]

96. Dong, L.; Zhang, G.; Cheng, X.; Wang, Y. Analysis of the contribution rate of climate change and anthropogenic activity to runoff variation in Nenjiang Basin, China. Hydrology 2017, 4, 58. [CrossRef]

97. Zeng, S.; Xia, J.; Du, H. Separating the effects of climate change and human activities on runoff over different time scales in the Zhang River basin. Stoch. Environ. Res. Risk Assess. 2014, 28, 401-413. [CrossRef]

98. Amirgaliev, N.; Gogol, L.; Zheksenbai, E.; Saianov, S. Regime of hydrochemical indicators of the Syrdarya River in the conditions of anthropogenic impacts. Ecol. Hydrofauna 2008, 2, 82-91.

99. Хасанзода, Г.; Шокирзода, Ш.; Давлатзода, К.; Касымов, Х.; Одилзода, У.; Гачуров, Ш.; Кулов, А.; Асматбеков, Ф.; Наджибуллоев, К. Социально-экономическое положение РеспубликиТаджикистан. Агентство по статистике приПрезиденте РеспубликиТаджикистан. Душанбе. Available online: https:/ / www.stat.tj/ru (accessed on 7 October 2020). 
100. Hamed, K.H.; Rao, A.R. A modified Mann-Kendall trend test for autocorrelated data. J. Hydrol. 1998, 204, 182-196. [CrossRef]

101. Yue, S.; Pilon, P.; Phinney, B.; Cavadias, G. The influence of autocorrelation on the ability to detect trend in hydrological series. Hydrol. Process. 2002, 16, 1807-1829. [CrossRef]

102. R Foundation for Statistical Computing. R: A Language and Environment for Statistical Computing; R Foundation for Statistical Computing: Vienna, Austria, 2015; Volume 2018, p. 2013. Available online: http:/ / www.R-project.org/ (accessed on 7 May 2021)

103. Patakamuri, S.; O'Brien, N.M. Modified Versions of Mann Kendall and Spearman's Rho Trend Tests 2019; R Foundation for Statistical Computing: Vienna, Austria, 2019; Volume 1, pp. 1-27. Available online: https:/ /CRAN.R-project.org/package=modifiedmk (accessed on 7 May 2021). 